\title{
Epidemiology and Etiology of Congenital Heart Diseases
}

\author{
Jarun Sayasathid ${ }^{1}$, Kanchapan Sukonpan ${ }^{2}$ and Naraporn Somboonna ${ }^{3}$ \\ ${ }^{1}$ Cardiac Center, Faculty of Medicine, Naresuan University, \\ 2 Department of Obstetrics and Gynecology, Buddhachinaraj Hospital, \\ ${ }^{3}$ Department of Microbiology, Faculty of Science, Chulalongkorn University \\ Thailand
}

\section{Introduction}

Congenital heart disease (CHD), the most common type of birth defect, is an abnormal cardiocirculatory structure or function present at birth, although the disease is often discovered later in life. During prenatal life, the incidence of cardiac defect is higher due to affected fetuses that are aborted. CHD stems from an alteration in the embryonic development from a normal structure, or a failure of a structure to properly develop beyond an early stage of embryonic and fetal development. The non-typical patterns of cardio-circulatory flow owning to an anatomical defect may significantly influence the structural and functional development of the remainder of the circulatory system. Additionally, postnatal events have a marked impact on the clinical presentation of a specific isolated malformation.

As CHD accounts for the most frequent cause of lethal malformation among infants, CHD is also considered a major problem affecting public health worldwide (Bernier et al., 2010). Despite the continuing progress in non-surgical and surgical treatments that allow for the survival of the majority of patients, some complex heart diseases are still associated with substantial morbidity and mortality. According to a report, $45 \%$ of infant deaths owing to congenital anomalies were caused by CHD in Western Europe. In Latin America, North America, Eastern Europe and the South Pacific region (including Japan) this proportion has been reported to be $35 \%, 37 \%, 42 \%$ and $48 \%$, respectively (Botto, 2003). 20\% of spontaneous abortions and $10 \%$ of stillbirths are attributed to CHD (Botto, 2001). CHD causes high morbidity and mortality among infants, and affects the quality of life during childhood and adulthood, depending on the progression of the disease (Majnener et al., 2008). It also affects social interactions and the quality of life for parents of children with CHD.

While newborns with the cardiac disorder are symptomatic and identified soon after birth, many others are not diagnosed until the disease progresses into a severe stage. Data from the Northern Region Pediatric Cardiology database suggest around 1 in 4 cases of congenital heart disease in the UK are diagnosed later in childhood (Petersen et al., 2003). The signs and symptoms of heart disease depend on the type and severity of the disease. Children with critical cardiac lesion generally exhibit high morbidity and mortality because the risk of morbidity and mortality increases as treatment and diagnosis is delayed.

The screening process is very important to detect congenital heart malformations. One of the major contributors to increased mortality and morbidity is clinical deterioration and heart 
failure prior to diagnosis and treatment. Early detection of CHD in the fetus or in the asymptomatic period immediately after birth will reduce clinical deterioration by instigation of appropriate management of the disease. Technical improvements in sonographic systems during the past two decades have helped the obstetric sonographers detect congenital heart anomalies, especially in experienced hands. A fetal cardiac screening with fetal echocardiography allows for early detection of $\mathrm{CHD}$ allowing for the option of pregnancy termination in cases of complicated defects. In areas where termination of pregnancy is a realistic and supported option, a universal sonographic screening of all pregnancies with an average reported sensitivity of $35 \%$ and a termination rate of $43 \%$ following prenatal diagnosis, would result in a $15 \%$ overall reduction of the prevalence of most severe forms of CHD (Germanakis \& Sifakis, 2006). The information from 20 registries of congenital malformation in 12 European countries demonstrated the overall prenatal detection rate of CHD was 25\% (Garne et al, 2001). Echocardiography can be used for screening in live birth infants. Newborn echocardiographic screening enables pediatricians to detect abnormal cardiac characteristics early and accurately, especially heart diseases without murmur such as coarctation of the aorta (Coarc), atrial septal defect (ASD), atrioventricular septal defect (AVSD), hypertrophic cardiomyopathy and cardiac tumor. In addition, cardiopulmonary information obtained from the echocardiographic examination can be useful for neonatal care providers (Wang et al., 2007).

The echocardiographic screening in developing countries may be difficult due to lack of echocardiographic machines and sonographers. Fortunately, most of patients with CHDs can be detected by clinical presentations and physical examinations. Approximately $90 \%$ of patients with CHDs were referred for cardiovascular evaluation with cardiac murmur, arrhythmia, cyanosis, palpitation and chest pain. False positives occurred $22.3 \%$ of the time with innocent (functional) murmur, and non organic chest pain or other non cardiac diagnosis (Borzouee \& Jannati, 2008). In a Toronto study, $0.28 \%$ of the school-age children were found to have innocent murmurs (Rose et al., 1964). Currently, infants are screened to detect CHD by clinical and physical examination after birth and another examination at 6-8 weeks. However, this screening program can detect only $50 \%$ of congenital defects (Knowles et al., 2005). Thailand has a lack of pediatric doctors and cardiologists, and, therefore, there has been training available for qualified nurses and health officers to screen patients for CHD using clinical and physical examinations. These screenings are not only for infants, but also for school-age children and adults too. Although we detected a lot of false positives from innocent murmurs and abnormal clinical presentations, we recognized many undiagnosed CHD patients and have found many CHD patients who choose to undergo proper treatment (Sayasathid et al., 2009, 2010). Another tool to recognize CHD is pulse oximetry. It can detect cyanotic CHD which are not detected by routine examination with high specificity $(99.8 \%)$ and very low false positive rate $(2 \%)$ although the sensitivity was only $63 \%$. Either functional or fractional oxygen saturation was measured by pulse oximetry with oxygen saturation below $95 \%$ as the cut-off level in most studies (Thangaratinam et al., 2007). Children who are suspected of having CHD should be referred to a pediatric cardiologist for definitive diagnosis, suitable treatment and follow up.

Nonetheless, the cost-effectiveness remains a concern, especially in developing countries. Costs are very different between screening using echocardiography versus clinical examination. A cost-effectiveness analysis study for screening 100,000 newborns in the UK showed the total program cost $£ 300,000$ for clinical examination, $£ 480,000$ for pulse oximetry and $£ 3.54$ million for screening echocardiography. The addition cost per additional timely 
diagnosis of life-threatening CHD ranges from $£ 4,900$ for pulse oximetry to $£ 4.5$ million for screening echocardiography (Knowles et al., 2005). Hence, the public health officers need to consider appropriate methods of CHD detections for their countries.

Although, there have been many studies to find the etiology of CHD, the cause of most CHDs continues to be unknown. Some reports suggested the cause to be a combination between genetic and environmental factors. Heart disease symptoms in a child are generally simple when compared with an adult, and have widely different pathology and physiology. Heart disease in an adult is a disease that often happens later in life (acquired heart disease) in the blood vessels (coronary artery disease) and heart valves. In this chapter, we will describe the possible causes and risk factors of CHD.

The first corrective surgery with cardiopulmonary bypass for intra-cardiac malformations began at the Mayo Clinic and the University of Minnesota Hospital in the 1950s (Lillehei, 1956). Through the past half century, the diagnosis and treatment of CHDs have markedly improved. The rapid evolution of diagnosis, medical and surgical therapies has reduced the morbidity and mortality rate. The surgical mortality has decreased from an average of $15 \%$ in 1990 to an average of 5\% in 2000 (Kenny, 2008, as cited in Gibbs et al., 2004). The majority of infants with CHD are now expected to survive into adolescence and adulthood. Currently, the number of adults diagnosed with CHD exceeds the number of children diagnosed with CHD. Hence, the objectives of this chapter are to describe epidemiology and etiology of CHD, including preventative guidelines for pregnant mothers. The authors hope this will provide essential overview to not only physicians and public health officers but also pregnant women, interested readers and societal awareness for the possibility of CHD in newborns. We also hope to provide appropriate strategies for managing the problem. This would lead to an appropriate health care budget and plan for diseased children in the future.

$\begin{array}{lll}\text { Abbreviations } & & \\ \text { AR } & = & \text { aortic regurgitation } \\ \text { AS } & = & \text { atrial septal defect } \\ \text { ASD } & = & \text { atrioventricular septal defect } \\ \text { AVSD } & = & \text { bicuspid aortic valve } \\ \text { BAV } & = & \text { congenital heart disease } \\ \text { CHD } & = & \text { coarctation of the aorta } \\ \text { Coarc } & = & \text { double outlet right ventricle } \\ \text { DORV } & = & \text { hypoplastic left heart } \\ \text { HLH } & = & \text { hypoplastic right heart } \\ \text { HRH } & = & \text { mitral regurgitation, (MVP = mitral valve prolapse) } \\ \text { IAA } & = & \text { pulmonary atresia } \\ \text { MR } & = & \text { patent ductus arteriosus } \\ \text { PA } & = & \text { pulmonary stenosis } \\ \text { PDA } & = & \text { single ventricle } \\ \text { PS } & = & \text { tricuspid atresia } \\ \text { SV } & = & \text { total/partial anomalous pulmonary venous return } \\ \text { TA } & = & \text { transposition of great arteries } \\ \text { T/PAPVR } & = & \text { tetralogy of Fallot } \\ \text { TGA } & = & \text { ventricular septal defect } \\ \text { TOF } & & \\ \text { VSD } & & \end{array}$




\section{Epidemiology of congenital heart diseases}

\subsection{Incidence rate}

The incidence of CHD refers to the number of newly identified cases, children or adult, depending on the degree of defective development of the individuals' heart, per unit of time or population. Incidence demonstrates the rate of disease. The incidence of congenital heart defect is difficult to precisely determine, partly because of difficulties in definition. However, not all cases of congenital heart disease are diagnosed in infancy. Incidence rates based on diagnoses in pregnant women and the first 12 months of the baby's life will, therefore, be an underestimate of true incidence. Accurate assessment of incidence of CHD is important in determining the etiology of $\mathrm{CHD}$, and in comparisons between populations over time, which might reflect population genetics or environment factors to a region or country. The incidence of CHD ranges from 4 to 85.9 per 1,000 pregnancies. Many congenital heart defects have been detected in stillbirths, particularly by an early loss in gestation due to chromosome anomalies. According to Hoffman (1978), the incidence of CHD among stillbirths is 79 per 1,000, whereas Mitchell (1972) reported an incidence of CHD in stillbirths and neonatal death (death after birth and before 28 days of age) to be 27.5 per 1,000 and 73.2 per 1,000, respectively. Yet, this number is likely an underestimate to the actual incidence of CHD because of difficulties in definition and unrecognized live births. The increasing incidence of CHD is primarily because of better methods of detection and data collection, as well as more advanced instruments, i.e. echocardiography, and highly skilled health officers. The increasing incidence of $\mathrm{CHD}$ could be due to more teratogenic environments affecting pregnant women and their offspring. Although an increased use of fetal echocardiography in pregnant women can help detect more CHD cases, many pregnancies are aborted prior to the mothers' awareness of the pregnancy and the effective assessment of a structural heart defect is still impossible for the early gestation phase. Moreover, the detection of heart malformation via fetal autopsy and heart examination remains rarely performed among the stillborns especially in developing country due to the lack of pathologists and the additional process for health professionals to request an autopsy.

\subsection{Birth prevalence}

Unlike incidence, the prevalence for CHD is the number of existing cases in the population of interest at one point in time. Prevalence represents the probability that a person in a given population will have the disease at a given time. Prevalence is a function of the incidence of the disease in a population and the duration of that disease. The sooner the recognition of birth prevalence of $\mathrm{CHD}$, the better the planning will be by hospitals, health officers, pediatricians, pediatric cardiologists and pediatric cardiac surgeons. Social and economic support can also be found early for the patients' families. The global prevalence of CHD among newborns ranges from approximately 3.7 to 17.5 per 1,000, which account for $30-45 \%$ of all congenital defects. In Northern England, birth prevalence of CHD was as high as 79.7 per 1,000 live births (Dadvand et al., 2008). The extreme variation of the birth prevalence might be owed to a single or a combination of the following factors: inclusion criteria, for example that reports include bicuspid aortic valve and tiny muscular VSD or not, specificity and sensitivity of the diagnostic methodologies, properly trained and technique specialty of examiners, and ethnic and regional backgrounds of the examinees. Additional factors might be associated with the unavoidable limits of the retrospective studies that the data depend on previous medical records, possibly incorrect registration, missing or insufficient co- 
ordination of cardiac pediatricians between outpatient and private clinics, and absence of autopsy to determine the cause of certain fetal death in stillbirths. Nonetheless, the estimation for birth prevalence of CHD remains simpler and more precise compared with the estimation for incidence of $\mathrm{CHD}$ from the baby population. Hence, most epidemiological studies report the birth prevalence rather than the baby incidence of CHD. Table 1 compares the birth prevalence of all CHD subtypes from 4 recent studies by Hoffman \& Kaplan, 2002 (review literatures); Reller et al., 2008 (Metropolian Atlanta Congenital Defects Program, MACDP); Dolk \& Loane, 2009 (European Surveillance of Congenital Anomalies, Eurocat) and $\mathrm{Wu}$ et al., 2010 (Asian population, Taiwan). Table 2 shows different percent distribution of $\mathrm{CHD}$ lesions in live births from various countries

\begin{tabular}{lcccc}
\hline $\begin{array}{c}\text { Cardiac } \\
\text { Lesion }\end{array}$ & $\begin{array}{c}\text { Hoffman \& } \\
\text { Kaplan, 2002* } \\
\text { Mean/Median }\end{array}$ & $\begin{array}{c}\text { Reller, 2008* } \\
\text { (MACDP) }\end{array}$ & $\begin{array}{c}\text { Dolk \& Loane, } \\
\text { 2009** } \\
\text { (Eurocat) }\end{array}$ & $\begin{array}{c}\text { Wu, 2010* } \\
\text { (Asian population) }\end{array}$ \\
\hline VSD & $3.57 / 2.83$ & 4.18 & 3.06 & 4.01 \\
PDA & $0.80 / 0.57$ & 0.29 & --- & 2.01 \\
ASD & $0.94 / 0.56$ & 1.31 & 2.05 & 3.23 \\
AVSD & $0.35 / 0.34$ & 0.41 & 0.19 & 0.20 \\
PA & $0.13 / 0.08$ & 0.04 & 0.09 & --- \\
PS & $0.73 / 0.53$ & 0.55 & 0.40 & 1.22 \\
AS & $0.40 / 0.26$ & 0.11 & 0.14 & 0.16 \\
Coarc & $0.41 / 0.36$ & 0.44 & 0.34 & 0.25 \\
TOF & $0.42 / 0.36$ & 0.47 & 0.28 & 0.63 \\
TGA & $0.32 / 0.30$ & 0.23 & 0.35 & 0.21 \\
HRH & $0.22 / 0.16$ & --- & 0.04 & -- \\
HLH & $0.27 / 0.27$ & 0.23 & 0.26 & 0.06 \\
TA & $0.08 / 0.09$ & 0.05 & 0.08 & 0.05 \\
Ebstein's & $0.11 / 0.04$ & 0.06 & 0.05 & 0.05 \\
Truncus & $0.11 / 0.09$ & 0.06 & 0.09 & 0.08 \\
DORV & $0.16 / 0.13$ & --- & --- & 0.15 \\
SV & $0.11 / 0.09$ & 0.10 & 0.07 & --- \\
TAPVR & $0.09 / 0.09$ & 0.08 & 0.05 & 0.11 \\
All CHD & $9.60 / 7.67^{* * *}$ & 8.14 & 7.05 & --08 \\
BAV & $13.56 / 9.24$ & --- & --- & - \\
\hline
\end{tabular}

*Live births

${ }^{* *}$ Non-chromosomal CHD prevalence (Includes: Live birth, Fetal death and Termination of pregnancy for fetal anomaly)

***Excluding bicuspid non-stenosis aortic valves, isolated partial anomalous pulmonary venous connection and silent ductus arteriosus

Table 1. Prevalence of CHD based on CHD subtypes and per 1,000 births compared among the four recent studies.

More importantly, the trend for birth prevalence of CHD was found to be increasing, highlighting three chief concerns. First, the increased number of CHD prevalence among the newborns could represent the greater number of adults with $\mathrm{CHD}$ and the likely increased number of CHD in their offspring in the future. This poses the concern about the overall 
increasing prevalence of CHD. A study in Hungary, estimates the prevalence of CHD to be $4.9 \%$ in offspring of individuals with CHD. More than half of these had the same malformation as the parent (Ceizel et al., 1981). Another study in 2001 showed the prevalence of CHD was 3.1\% in offspring of individuals with CHDs and $1.3 \%$ in offspring of individuals without CHDs. The adjusted risk for offspring of parents with CHDs was 1.73 (95\% CI, p=0.02) (Romano-Zelekha et al., 2001). On the other hand, if the high prevalence is due to the more common use of postnatal echocardiography for abnormal heart diagnosis, the greater birth prevalence of CHD signifies an underestimation of CHD among live births in the past and the importance for public health officers to have an accurate number of cases. For instance, fetal echocardiography screening could be performed to decide pregnancy termination of fetuses with severe cardiac malformation, and thereby reduce the birth prevalence of CHD. Finally, the rapid development of the world may increase many risk factors to develop CHD such as pollutants and teratogens. The number of births with CHD in Dallas county suggests an apparent increase in prevalence from approximately $5 \%$ in 1971 to 8\% in 1984 (Fixler et al., 1990). Within the Baltimore-Washington Infant Study Group, the prevalence of CHD increased from 2.8 per 1,000 live births in 1981 to 4.3 per 1,000 live births in 1988 (Ferencz et al., 1989) and a recent report from North England demonstrated the total prevalence of CHD increased from 5.4 per 1,000 births and terminations of pregnancy in 1985 to 11.6 per 1,000 births and terminations of pregnancy in 2003 (Dadvand et al., 2008).

\begin{tabular}{|c|c|c|c|c|c|c|c|c|c|}
\hline \multirow{2}{*}{ Cardiac Lesio } & USA $^{1}$ & UK $^{2}$ & USA $^{4}$ & India $^{5}$ & Saudi ${ }^{*}$ & Jordan $^{7}$ & \multicolumn{2}{|c|}{ Bangla $^{8^{*}}$} & Germany $^{9}$ \\
\hline & & & & & & & & & \\
\hline VSD & 29.1 & 28.1 & 32.5 & 26.3 & 34.8 & 33.9 & 43.4 & 16.9 & 48.9 \\
\hline VSD+PS & 2.4 & 8.6 & --- & --- & --- & --- & --- & --- & --- \\
\hline PDA & 7.6 & 6.5 & 11.9 & 2.6 & 18.6 & 11.6 & 8.3 & 12.7 & 4.3 \\
\hline ASD & 7.4 & 8.3 & 5.9 & 7.5 & 2.3 & 18.1 & 13.6 & 26.0 & 17.0 \\
\hline AVSD & 4.3 & 7.4 & 2.4 & --- & 2.3 & 3.5 & 3.6 & 3.5 & 2.7 \\
\hline PA & --- & --- & 0.8 & --- & --- & --- & --- & 2.8 & 0.9 \\
\hline PS & 8.1 & 2.7 & 7.5 & 7.0 & --- & 12.4 & 6.2 & 7.8 & 6.1 \\
\hline AS & 3.5 & 4.1 & 5.1 & 3.3 & 2.3 & 2.5 & 4.3 & 1.4 & 2.2 \\
\hline Coarc & 4.3 & 5.6 & 6.3 & 6.8 & --- & 2.3 & 3.4 & 2.1 & 3.6 \\
\hline TOF & 3.5 & --- & 5.9 & 9.2 & 4.6 & 3.5 & 9.5 & 9.9 & 2.5 \\
\hline d-TGA & 2.4 & 5.6 & 5.0 & 5.0 & --- & 2.1 & 5.5 & 4.2 & 2.2 \\
\hline HLH & -- & 3.3 & 2.8 & 5.7 & 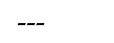 & --- & -- & $-\ldots$ & 1.4 \\
\hline TA & 1.1 & 1.5 & 1.7 & 1.5 & 2.3 & --- & 3.7 & 3.5 & --- \\
\hline Ebstein's & --- & -- & --- & --- & --- & --- & --- & --- & 0.4 \\
\hline Truncus & --- & 1.2 & 1.1 & --- & --- & --- & --- & 0.7 & 0.5 \\
\hline DORV & 1.1 & --- & -- & --- & --- & --- & --- & --- & 1.0 \\
\hline SV & 0.9 & 1.5 & 1.7 & & 2.3 & --- & --- & 1.4 & --- \\
\hline TAPVR & -- & 2.1 & 1.3 & 1.7 & --- & --- & --- & 1.4 & 0.6 \\
\hline MR & 0.6 & --- & --- & --- & --- & --- & --- & --- & --- \\
\hline
\end{tabular}

${ }^{1}$ Mitchell et al., 1971, ${ }^{2}$ Bound \& Logan, 1977, ${ }^{3}$ Dickinson et al., 1981, ${ }^{4}$ Ferncz et al., 1985, ${ }^{5}$ Khalil et al., 1994, ${ }^{6}$ Alabdulgader, 2006, 7 Amro, 2009, 8 Fatema et al., 2008, ${ }^{9}$ Lindinger et al., 2010

*Saudi = Saudi Arabia, and Bangla = Bangladesh

Table 2. Percent distribution of CHD lesions in live births in USA, UK, India, Saudi Arabia, Jordan, Bangladesh and Germany. 


\subsection{Adult prevalence}

Similar to the knowledge of birth prevalence, the knowledge of adult prevalence can estimate the need for adult cardiology services. The accurate prevalence of CHD in the adult population is difficult to know. Although some patients with $\mathrm{CHD}$ have spontaneous recovery, for instance 35\% of infants with VSD had their lesion close spontaneously (Mitchell et al., 1971), an overall number of adult diagnosed with CHD continues to rise and is now higher than that of the diagnosed pediatric cases. It was estimated that in 2000 there were fewer than 150,000 adults diagnosed with CHD in the UK. Of these, around 11,500 had the more complex forms of the disease, requiring life-long expert supervision and intervention (Report of the British Cardiac Society Working Party, 2002). It was also further estimated that by the year 2010 there would be over 185,000 adults in the UK living with CHD (over 17,000 with the complex form), a rise of around $25 \%$ in simple and $50 \%$ in complex conditions since 2000. Using a birth prevalence of CHD of 8.8 per 1,000 live births, it is estimated that more than 8,500 individuals with surgical repair of congenital heart defects reach adulthood each year in the USA (Morris, 2004). In year 2000, approximately 500,000 American adults were reported to have moderate to complex congenital heart defects. By 2020, nearly 760,000 adults will have CHD in the USA, with 200,000 having severe CHD, disregarding all those born before 1990 (Webb et al., 2002). Our review has only one study that reports exactly the adult prevalence of CHD. This study was done in a general population from 1985 to 2000 in Canada, it revealed the prevalence of CHD was 4.09 per 1,000 adults for all CHD and 0.38 per 1,000 for those with severe lesions (Table3). $57 \%$ of the adult CHD population was female (Marelli et al., 2007). The authors extrapolated a prevalence of 4.09 per 1,000 to a Canadian and US population corresponds to 96,000 patients in Canada and 856,000 patients in the United States. A recent study in the Netherlands studied 8,595 adults with CHD, and found the most common defects in the distribution of CHD were ASD (17\%), VSD (16\%), AS/BAV (14\%), TOF $(10 \%)$ and Coarc $(10 \%)$ but the highest mortality was found in patients with TA (14.7\%) and patients with UV and double inlet left ventricle (11.4\%)(Zomer et al., 2010).

Two main reasons can explain this situation. First, there is the process of natural selection in which children with previously undetected CHD or children with inoperable CHD survive into adulthood with uncorrected lesions. Up to $75 \%$ of children with CHD did not exhibit clinical signs of diseases until the diseases became severe. Moreover, around $10 \%$ of $\mathrm{CHD}$ are not diagnosed until adulthood (Mettler \& Peeler, 2009), in particular secundum atrial septum defect, ventricular septal defect, pulmonary stenosis, anormalous coronary arteries, Ebstein's anomaly and congenitally corrected transposition of great arteries. One of the more recent CHD studies in Thailand reported 0.41 to 1.05 prevalent cases of unrecognized CHD for every 1,000 elementary-age students. This variation was due to the topography and the limitation of medical staff and facilities in the study areas. In this population, the most frequently identified heart defects were VSD 41.4\%, PS 16.1\%, PDA $12.6 \%$ and ASD 9.2\% (Sayasathid, et al., 2010). The second reason is the improvement of surgical therapy and postoperative care of neonates and infants in the past few decades, this has led to increased survival of children with CHD. Currently, more than $90 \%$ of children born with CHD can survive into adulthood (Moons et al., 2009). From 1979 through 1997, mortality associated with CHD (all ages) declined 39\% from 2.5 to 1.5 per 100,000 (Boneva et al., 2001). Although many children with CHD cannot be cured, the initial therapy, including corrective and palliative, allows the adult prevalence of $\mathrm{CHD}$ to continue to increase. At Mayo clinic, the number of adult patients with CHD who undergo operation has grown to approximately 
300-400 patients per year (Brown et al., 2009). These patients have elevated risk of premature morbidity and mortality. CHD is often more severe and has more complicated treatment in adults than children. Moreover, a recent analysis of the United States administrative database found that mortality was greater for adults with CHD when the operations were performed by adult cardiac surgeons, compared with pediatric (congenital-trained) heart surgeons (4.8\% versus 1.9\%, $\mathrm{P}<0.001$ ) (Brown et al., 2009, as cited in Karamalou et al., 2008). For CHD adults, arrhythmias are more common, cardiac chambers often enlarge, and ventricles tend to develop systolic dysfunction. The main causes of death were progressive heart failure $26 \%$ and sudden cardiac arrest 22\% (Zomer et al., 2010). Multidisciplinary care may also be required.

\begin{tabular}{cc}
\hline Lesion & prevalence per 1,000 adults \\
\hline & \\
Severe lesion & 0.17 \\
TOF or truncus & 0.14 \\
AVSD & 0.04 \\
TGA & 0.03 \\
SV & 0.38 \\
All severe lesions & \\
& \\
Other lesion & 0.88 \\
ASD & 0.78 \\
VSD & 0.02 \\
PDA & 0.11 \\
AS or AR & 0.07 \\
Coarc & 0.01 \\
Ebstein's & 3.71 \\
All other lesions & 4.09 \\
\hline
\end{tabular}

Table 3. The prevalence of adult CHD based on subtypes in year 2000, Canada (Marelli et al., 2007).

Another problem that should be of concern is the transfer system from pediatric to adult health care. Many children with CHD did not follow-up when they were discharged from pediatric care and referred to adult care. In a Canadian study, only $47 \%$ of teenagers with CHD had transferred successfully to adult care (Reid et al., 2004). The results were similar in a German study, 76\% of patients with CHD did not have follow-up care as an adult in a 5year period (Wacker et al., 2005). The prevalence of adults with CHD is underestimated if it does not include this group of patients. These patients received medical care again when their diseases had progressed and their symptoms had become severe. This lack of care as an adult made it difficult to manage the disease and resulted in high morbidity \& mortality in these patients. Patients with CHD must recognize the necessesity of ongoing surveillance and the transfer system must be developed to prevent the loss of follow-up patients.

\section{Etiology of congenital heart diseases}

The heart development, which initiates at embryonic day 15 in vertebrates, comprises an organized series of molecular and morphologic events that involve five primary steps: (1) 
migration of pre-cardiac cells from the primitive streak and assembly of the paired cardiac crescents at the myocardial plate, (2) coalescence of the cardiac crescents to form the primitive heart tube, establishment of the definitive heart, (3) cardiac looping, assurance of proper alignment of the future cardiac chambers, (4) septation and heart chamber formation, and (5) development of the cardiac conduction system and coronary vasculature (McFadden \& Olson, 2002; Moorman \& Christoffels, 2003; Gittenberger-de Groot et al., 2005). From a series of complex processes, each component occurs at the right time under the orchestration of a cascade of genes and gene products, resulting in the coordination of cell migration and the formation of the extracellular matrix. Thus, CHD is usually caused by altered development of embryonic structure, or a failure of the structure to develop beyond an early embryonic or fetal stage. The anatomical defect generally influences further structural and functional development. Although descriptions of abnormal heart development in fetuses and babies have remained unclearly defined, substantial knowledge about the etiology of CHD have been made during the last decade. Some malformations may be directly inherited through vertical gene transfer, underlying the individuals' genetic disorder, or be associated with the consequences of an environmental toxin or diet. Alternatively, random errors in cell migration leading to improper cardiac development are possible. Together, the findings emphasize the complex and multifactorial causes of the CHD where additional research remain needed.

Better understanding for the etiology and risk factors of CHD is important, and will help pave the way for proper preventative measures and treatment guidelines by physicians as well as public health officers. The followings represent all reported potential causes of CHD to date.

\subsection{Genetic disorders}

The human genome, which contains approximately 20,000 to 25,000 genes, is comprised of coding and non-coding regions that are essential for proper protein structure and expression. The coding DNA sequence determines the amino acid sequence and subsequently the protein structure, and structure determines function (Lander, 2011; ReidLombardo \& Bartelings, 2010). The non-coding sequences may contain promoters and regulation of transcription. In general, the DNA sequences remain relatively unchanged during vertical genetic transfer to the offspring. Nonetheless, occasional changes in the nucleotide sequences, referred to as mutations, and horizontal gene transfer do occur. Mutations range from a single nucleotide substitution, also called single nucleotide polymorphism (SNP), to a deletion or insertion of a DNA fragment. Some mutations only appear visible at the level of the chromosome (chromosome abnormalities), while some mutations cause phenotypic changes and a heritable trait to the offspring.

Any change in the DNA sequence, including SNPs, insertion, deletion and shuffling of DNA fragment, that results in frameshift mutation of the gene-encoding sequence likely affects protein folding and protein function. Abnormal protein folding structure and function can cause an improper development of many organs, including the heart. Hence, genetics is responsible for one major role in cardiovascular malformation, and indeed the genetic disorders represent the most common cause of CHD. Certain chromosome abnormities were linked to specific types of congenital heart lesions, and several types have been reported to be associated with specific gene defects. For instances, AVSD are often diagnosed in patients with trisomy 21. 
Moreover, CHD that occur in multiple members of a family increases the incidence of CHD in familial lines, and support evidences of inherited genetic disorders towards the heart abnormities. Molecular genetics in conjunction with cytogenetics provide an opportunity to decipher the genetic basis and pathogenesis of CHD. With the rapid era of DNA sequencing and genetic discoveries, it is expected that genetic diagnosis and screening will become incorporated into standard practice in the near future. Consequently, it is imperative that cardiologists understand the basis for genetic disorders, and the medical and ethical implications relevant to the genetic information. Today, genetics are predisposed to malformation of the hearts and blood vessels, and account for the highest number of human birth defects. Thus, hereditary and congenital diseases are classified into three broad categories

\subsubsection{Chromosome defect}

Defects in chromosomes associated with CHD are diverse; some examples are aneuploidy or polyploidy, improper rearrangement during mitosis and meiosis, translocation, inversion or deletions. Importantly, certain chromosomes were reported to have a greater degree of significance and of percentages to heart development, and thus the same defects in different chromosomes may not result in similar defects (Table 4). About $0.30-2.0 \%$ of all live births have chromosomal defects, usually the chromosomal defects were aneuploidy and trisomy 21, 18, 13 (Dolk et al., 2010). Among all CHDs detected during infant period, the chromosomal defects account for approximately 6 - 10\% (Ferencz et al., 1989; Tennstedt et al., 1999; Zhang et al., 2010). In Table 4, defects in chromosomes $X, 3,4,5,7,8,9,10,11,13$, 17, 18, 21 and 22 showed association with CHD.

Nonetheless, the table summarizes the data reported by different studies, some conducted in different times and places. The incidence of CHD generally depends on multiple factors besides the type of genetic disorders and the chromosome where the disorders take place. The other factors include how many fetuses are conceived by the mothers, and how many of these fetuses reach term alive. Further, the affected number of fetuses also depends on the rate of the survival of the affected fetuses and the increased use of therapeutic abortion.

\subsubsection{Single gene disorder}

Heart development is controlled by multiple genes regulating a complicated network of transcription regulation, translation regulation, and signal transduction pathways, ranging from a control of muscle growth, patterning to contractility, to name a few. However, mutations in only one or a few components of the cardiac gene network can result in the improper development of the heart. One type of heart defect could also be caused by different types of single gene disorders. Since the 1990s, researchers have identified more than 10 different single gene mutations that can lead to heart defects. To date, many genes responsible for several congenital heart defects have been identified (table 5).

Transcription Factor Genes transcribe and translate proteins that serve to interact cooperatively with each other to control gene expression.

- NKX2-5, the NK family, on chromosome 5q35; Homeobox-containing genes play critical roles in regulating tissue-specific gene expression essential for specification of heart muscle progenitors (Komuro \& Izumo, 1993; Toko et al., 2002). Mutations in NKX2-5 result in loss of heart formation in the embryo and have been found in sporadic 
CCVM. Although the contributions of these variants to the disease phenotype remains uncertain, the linkage between this gene disorder and the atrioventricular conduction defect, ASD, VSD or TOF, have been found (Elliott et al., 2003; McElhinney et al., 2003; Stallmeyer et al., 2010).

- TBX1, T-box 1 transcription factor, the T-box family; The human TBX1 gene encodes another T-box transcription factor, expressed in neural crest and the developing cardiac outflow tract (conotruncus) (Calmont et al., 2009). Microdeletion TBX1 gene, located on chromosomal 22q11, causes DiGeorge syndrome, also known as Velocardiofacial syndrome. There are variable ranges of clinical phenotypes for DiGeorge syndrome, including IAA, truncus arteriosus, TOF, DORV and TGA (Jerome \& Papaioannou, 2001; Xu et al., 2004; Yagi et al., 2003).

- TBX5, T-box 5 transcription factor, the T-box family; is a member of a phylogenetically conserved family of genes that share a common DNA-binding domain, the T-box. TBX5 was found expressed in embryonic human heart and limb. Mutations in this gene have been associated with Holt-Oram syndrome (Fan et al., 2003), which is characterized by skeletal malformations of the upper extremities and CHD, most commonly secundum ASD but also VSD and TOF (Basson et al., 1999; Faria et al., 2008; Li et al., 1997; Xin et al., 2009).

- $\quad$ GATA4, GATA binding protein 4; is related to zinc finger transcription factors. This protein is thought to regulate genes involved in embryogenesis and in myocardial differentiation and function. Furthermore, GATA4 interacts with Tbx5 and with Nkx2-5 to regulate cardiac gene expression. This provides evidence that a transcriptional complex including all three proteins may be necessary for proper septation of the human heart. Mutations in this gene have been associated with non-syndromic CHD cardiac septal defects (Gang et al., 2003; Tomita-Mitchell et al., 2007).

- TFAP2B, transcription factor AP-2 beta; This gene encodes a member of the AP-2 family of transcription factors. This protein functions in the differentiation of neural crest cell derivatives, and contributes to the embryogenesis of the ductus arteriosus (Hilger-Eversheim et al., 2000). Mutations in this gene result in autosomal dominant Char syndrome, a dominant disorder comprised of facial dysmorphism, hand anomalies, and patent ductus arteriosus (Mani et al., 2005; Satoda et al., 2000; Zhao et al., 2001).

- ZFPM2/FOG2, zinc finger protein, multitype 2; The zinc finger protein encoded by this gene is a widely expressed member of the FOG family of transcription factors. The FOG family members modulate the activity of co-factors with the GATA family of proteins, which are important regulators of hematopoiesis and cardiogenesis in mammals. In experimental gene targeting of ZFPM2/FOG2 in mice, the mutation resulted in cardiac malformation including TOF, endothelial specific disruption (DORV, a common AV valve), VSD and ASD as well as left ventricular wall hypoplasia, and the failure to form coronary arteries (Tevosian et al., 2000). Recent reports found mutations of the ZFPM2/FOG2 gene associated with TOF (De Luca et al., 2010; Pizzuti et al., 2003).

- ZIC3, Zic family member 3 heterotaxy 1; This gene encodes a member of the ZIC family of $\mathrm{C} 2 \mathrm{H} 2-$ type zinc finger proteins. Mutations in ZIC3 gene, located at chromosome Xq24-q27.1 (Casey et al., 1993), cause X-linked visceral heterotaxy and 
complex CHD including ASD, AVSD, TGA, PS, and TAPVR (Zhu et al., 2007; Grinberg \& Millen, 2005).

Cell signaling genes produce proteins involved in cell signal transduction, which allow cells to respond to their environment and are therefore involved in regulation of many important biological functions.

- JAG1, Jagged 1; The jagged 1 protein encoded by JAG1 is the human homolog of the Drosophila jagged protein. Human jagged 1 is the ligand for the receptor NOTCH, which is essential in many organ developmental programs. Analysis of JAG1 expression during mammalian embryogenesis showed its high level of gene expression during the heart and vessel developing periods, and the finding was consistent with the crucial role of its patterning of the right heart and pulmonary vasculature (Loomes et al., 1999). Mutations in the jagged 1 protein cause Alagille syndrome, a complex disease characterized by liver problem, PS, and with or without TOF (Heritage et al., 2002; McElhinney et al., 2002; Colliton et al., 2001).

- NOTCH1, NOTCH2, The NOTCH family receptors; The NOTCH gene encodes a single-pass transmembrane protein receptor that interacts with the ligands named Delta and Serrate/Jagged, and perform many cellular regulatory function. Mutations in NOTCH1 have been shown to cause autosomal-dominant aortic valve defects, and bicuspid (two-leaflet) aortic valve (Grag et al., 2005; McKellar et al., 2007; Mohamed et al., 2006). Because BAV is a risk factor for valve calcification, it has previously been hypothesized that calcification was due to increased blood flow turbulence across the valve leaflets (Robicsek et al., 2004), leading to progressive aortic stenosis and regurgitation in later life. Furthermore, mutation in NOTCH2 receptor was recently found to be able to cause Alagille syndrome even in the patients with no Jagged1 mutations (El-Rassy et al., 2008; McDaniell et al., 2006).

- PTPN11; The protein encoded by this gene is a member of the protein tyrosine phosphatase (PTP) family. PTPs are known to be signaling molecules that regulate a variety of cellular processes including cell growth, differentiation, mitotic cycle, and oncogenic transformation. Mutations in this gene are a cause of Noonan syndrome, located on chromosome 12q24 (Jamieson et al., 1994), it is an autosomal dominant disorder characterized by dysmorphic facial features, skeletal malformations, short stature, and cardiac abnormalities, most characteristic are PS, ASD, AVSD and hypertrophic cardiomyopathy (Jongmans et al., 2005; Sarkozy et al., 2003).

- CFC1, cryptic family 1; This gene encodes a member of the EGF-Cripto, Frl-1, and Cryptic (CFC) family. These proteins play key roles in intercellular signaling pathways during vertebrate embryogenesis. This protein is involved in left-right asymmetric morphogenesis during organ development. Mutations in this gene can cause autosomal visceral heterotaxy with complex CHD including TGA, septal defects and systemic vein anomalies (Goldmuntz et al., 2002; Ozcelik et al., 2006; Yan et al., 1999).

- SOS1, son of sevenless homolog 1; This gene encodes a protein that is a guanine nucleotide exchange factor for RAS proteins, membrane proteins that bind guanine nucleotides and participate in signal transduction pathways. Mutations in this gene are associated with gingival fibromatosis 1 and Noonan syndrome (Serrano-Martin et al., 2008). 
- PROSIT240, also known as THRAP2; An evolutionarily conserved THRAP genes encode a family of proteins that regulate embryonic development. Missense mutation PROSIT240 gene has been identified as a cause of transposition of the great arteries (Muncke et al., 2003).

- CRELD1, cysteine-rich with EGF-like domains 1; CRELD1 is the member of a family of matrix cellular proteins. Matrix cellular proteins contain epidermal growth factor-like repeats, and are grouped in a class of cysteine-rich domains that mediate interactions between proteins of diverse functions. Mutation in CRELD1 genes, locating on chromosome 3p25 locus, represents a vital gene position for AVSD (Guo et al., 2010; Zatyka et al., 2005; Robinson et al., 2003).

- EVC, EVC2; This gene encodes a protein containing a leucine zipper and a transmembrane domain. The functions of EVC and EVC2, which share a promoter, are aligned in control limb, skeleton and teeth development. Mutation of this gene has been implicated in both Ellis-van Creveld syndrome and Weyers acrodental dysostosis, the disease locus mapped to chromosome 4p16 (Polymeropoulos et al., 1996). Ellis-van Creveld syndrome is an autosomal recessive disorder characterized by chondrodysplasia and CHD, typically a common atrium of the atrioventricular septal defect type or secundum type atrial septal defects (Ali et al., 2010; Hills et al., 2011; Tompson et al., 2007). Some heterozygous carriers of these mutations manifested Weyers acrodental dysostosis suggesting it is allelic with Ellis-van Creveld syndrome (Riiz-Perez et al., 2000).

- TGFBR1 and TGFBR2, transforming growth factor receptor 1 and 2; This gene encodes a member of the Ser/Thr protein kinase family and the TGFB receptor subfamily. Mutations in this gene have been associated with Marfan syndrome, LoeysDeitz Aortic Aneurysm syndrome (Loeys et al., 2006; Singh et al., 2006).

Extracellular Matrix Protein Genes encode extracellular matrix proteins which cause congenital syndromes involving arteriopathies of different forms.

- $\quad$ ELN, elastin; This gene encodes a protein is one of the two components of elastic fibers. It resides in the Williams critical region on 7q11.23. Deletions and mutations in this gene are associated with Williams or Williams-Beuren syndrome in which the phenotype is comprised of characteristic endocrine, cognitive, and facial features in association with areas of arterial narrowing, most typically non-syndromic supravalvular AS (Micale et al., 2010; Rodriguez-Revenga et al., 2005; Arrington et al., 2006).

- FBN1, fibrillin 1; This gene encodes a member of the fibrillin family. This fibrillin has long been assumed to be critical in the aortic wall and other connective tissues as a structural protein. Mutations in this gene are associated with Marfan syndrome (Brautbar et al., 2010; De Backer, 2009; Li et al., 2008). Marfan syndrome is an autosomal dominant disease of connective tissue principally involving the skeletal, ocular systems and cardiovascular malformation whose manifestations include mitral valve prolapse and regurgitation, presenting in infancy in the most severe cases, and progressive aneurismal dilation of the aortic root with the potential for catastrophic aortic dissection and rupture. Marfan syndrome was first mapped to chromosome 15 using traditional genetic linkage analysis (Dietz et al., 1991). Other studies have revealed that fibrillin has a regulatory role in TGF- signaling, and dysregulation of the pathway may instead underlie Marfan pathogenesis (Neptune et al., 2003). 


\begin{tabular}{|c|c|c|c|}
\hline Type of abnormality & Predominant of CHD & Percentage of CHD & Reference \\
\hline \multicolumn{4}{|l|}{$\begin{array}{l}\text { Numeric aberrations; } \\
\text { Autosomes: }\end{array}$} \\
\hline \multicolumn{4}{|l|}{ - Monosomy } \\
\hline$X$ (Turner syndrome) & $\begin{array}{l}\text { Left-sided obstruction, PAPVR, MVP, } \\
\text { aortic route dilatation }\end{array}$ & 35 & $1-5$ \\
\hline \multicolumn{4}{|l|}{ - $\underline{\text { Trisomy }}$} \\
\hline 13 (Patau syndrome) & VSD, PDA, ASD, dextroposition & $80-90$ & $6-8$ \\
\hline 18 (Eward syndrome) & VSD, PDA, ASD, TOF, DORV, CPVD & $80-100$ & $9-11$ \\
\hline $\begin{array}{l}21 \text { (Down syndrome) } \\
\text { - Tetrasomy }\end{array}$ & VSD, AVSD, ASD & $40-50$ & 12,13 \\
\hline $\begin{array}{l}\text { 22pter-q11 } \\
\text { (Cat-Eye syndrome) }\end{array}$ & TAPVR, HLH & 40 & $14-16$ \\
\hline
\end{tabular}

Structural aberrations;

- Duplication

3q26-27 (Cornelia de Lange)

\section{PS, VSD, ASD, DORV}

VSD, TA

$8 \mathrm{q}$

$9 \mathrm{p}$

$11 \mathrm{q}$

- Deletion

3p (3p-syndrome)

$4 p$ (Wolf-Hirschhorn)

$4 \mathrm{q}$

$5 \mathrm{p}$ (Cri du chat syndrome)

$8 \mathrm{p}$ (8p-syndrome)

$10 \mathrm{p}$

11q (Jacobsen syndrome)

$18 \mathrm{p}$

$18 \mathrm{q}$

- Microdeletion

7q11 (Williams syndrome)

17p11.2 (Smith-Magenis syndrome)

22q11.2 (DiGeorge syndrome)
ASD

ASD

AVSD

ASD, VSD, PDA, PS

ASD, VSD, PS

VSD, PDA, TOF

AVSD

VSD, ASD, PS

VSD, left heart obstructive

malformations, HLH

VSD, PDA, PS, heterotaxy phenotype

ASD, VSD, PS

SVAS, PS

e) VSD, ASD, PS, AV malformation

TOF, TAPVR

Aortic arch anomalies, IAA type $B$, TOF, TA, ASCA

\begin{tabular}{ll}
40 & $17-19$ \\
45 & 20,21 \\
40 & 22 \\
35 & 22 \\
& \\
25 & 23,24 \\
$30-50$ & 25 \\
50 & $26-28$ \\
30 & 29 \\
$65-80$ & 30,31 \\
50 & 32,33 \\
60 & 34,35 \\
10 & 36,37 \\
30 & 38,39 \\
60 & 40,41 \\
30 & 42,43 \\
$75-85$ & 44,45 \\
\hline
\end{tabular}

ASCA: aberrant subclavian artery, CPVD: congenital polyvalvular disease, CVM: cardiovascular malformations, DCM: dilated cardiomyopathy, RAA: right aortic arch, SVAS: supravalvular aortic stenosis (Ref: ${ }^{2}$ Douchin et al., 2000; ${ }^{2}$ Lichiardopol \& Morta, 2004; ${ }^{3}$ Mazzanti \& Cacciari, 1998; ${ }^{2}$ oprawski et al., 2009; ${ }^{T}$ Tan \& Yeo, 2009; ${ }^{6}$ Lin et al., 2007; ${ }^{7}$ Lizarraga et al., 1991; ${ }^{8}$ Musewe et al., 1990; ${ }^{9}$ Van Praagh et al., 1989; ${ }^{10}$ Matsuka et al., 1981; ${ }^{11}$ Musewe et al., 1990; ${ }^{2}$ Paladini et al., 2000; ${ }^{13}$ Weijerman et al., 2010;

${ }^{14}$ Berends et al., 2001; ${ }^{15}$ Rosias et al., 2001; ${ }^{16}$ Wilson et al., 1984; ${ }^{17}$ Akdeniz et al., 2009; ${ }^{18}$ Barisic et al., 2008; ${ }^{19}$ Selicorni et al., 2009; ${ }^{20}$ Digilio et al., 2003; ${ }^{21}$ Giltay et al., 1998; ${ }^{22}$ Roskers et al., 1990; ${ }^{23}$ Green et al., 2000; ${ }^{24}$ Shuib et al., 2009; ${ }^{25}$ Battaglia et al., 1999; ${ }^{26}$ Tsai et al., 1999; ${ }^{27}$ Strehle \& Bantock, 2003; ${ }^{28} \mathrm{Huang}$ et al., 2002; ${ }^{29}$ Hills et al., 2006; ${ }^{30}$ Devriendt et al., 1999; ${ }^{31}$ Wat et al., 2009; ${ }^{32}$ Lindstrand et al., 2010; ${ }^{33}$ Van Esch et al., 1999; ${ }^{34}$ Grossfeld et al., 2004; ${ }^{35}$ Mattina et al., 2009; ${ }^{36}$ Digilio et al., 2000; ${ }^{37}$ Movahhedian et al., 1991; ${ }^{38}$ Cody et al., 1999; ${ }^{39}$ Linnandivi et al., 2006; ${ }^{40}$ Eronen et al., 2002;41Ferrero et al., 2007; ${ }^{42}$ Edelman et al., 2007;43Potocki et al., 2003; ${ }^{44}$ Ballesta et al., 2008; ${ }^{45}$ Shprintzen, 2008)

Table 4. Chromosome abnormality associated with congenital heart anomalies and their percentages. 


\begin{tabular}{|c|c|c|c|c|}
\hline Gene & Syndrome & $\begin{array}{l}\text { Chromosome } \\
\text { location }\end{array}$ & Inheritance & $\begin{array}{l}\text { Congenital heart } \\
\text { malformation }\end{array}$ \\
\hline \multicolumn{5}{|c|}{ Transcription Factor Gene } \\
\hline NKX2-5 & Non-syndromic & $5 q 34$ & $\mathrm{AD}$ & $\begin{array}{l}\text { ASD, AVB, VSD, TOF, } \\
\text { HCM, TV abnormality }\end{array}$ \\
\hline TBX1 & DiGeorge Syndrome & $22 q 11.21$ & Sporadic & VSD, PTA, IAA, TOF \\
\hline TBX5 & Holt-Oram Syndrome & $12 \mathrm{q} 24.1$ & $\mathrm{AD}$ & $\begin{array}{l}\text { HOS, ASD, AVSD, AVB, } \\
\text { TOF, TAPVR, TA, PS }\end{array}$ \\
\hline GATA4 & Non-syndromic & $8 \mathrm{p} 23.1 \mathrm{p} 22$ & $\mathrm{AD}$ & ASD \\
\hline TFAP2B & Char syndrome & $6 \mathrm{p} 12$ & $\mathrm{AD}$ & PDA \\
\hline ZFPM2/FOG2 & Non-syndromic & $8 q 23$ & Sporadic & TOF \\
\hline ZIC3 & HeterotaxySyndrome & $\mathrm{Xq} 26$ & X-linked & $\begin{array}{l}\text { Heterotaxy, ASD, AVSD, } \\
\text { TGA, PS, DORV, TAPVR }\end{array}$ \\
\hline \multicolumn{5}{|c|}{ Cell signaling Genes } \\
\hline Jagged 1 & Alagille Syndrome & 20p12 & $\mathrm{AD}$ & PS, TOF \\
\hline NOTCH1 & Non-syndromic & $9 q 34-35$ & Sporadic & BAV \\
\hline NOTCH2 & Alagille Syndrome & $1 \mathrm{p} 12$ & $\mathrm{AD}$ & PS, TOF \\
\hline PTPN11 & Noonan syndrome & $12 q 24$ & $\mathrm{AD}$ & $\begin{array}{l}\text { PS, PV dysplasia, ASD, } \\
\text { AVSD, HCM }\end{array}$ \\
\hline $\mathrm{CFC} 1$ & Heterotaxy syndrome & $2 q 21$ & Unknown & Heterotaxy, TGA, DORV \\
\hline SOS1 & Noonan syndrome & $2 \mathrm{p} 21$ & $\mathrm{AD}$ & PS, septal defect, HCM \\
\hline PROSIT240 & Non-syndromic & $12 \mathrm{q} 24$ & Unknown & TGA \\
\hline CRELD1 & Non-syndromic & $3 \mathrm{p} 21$ & Sporadic & AVSD \\
\hline EVC/EVC2 & $\begin{array}{l}\text { Ellis- van Creveld } \\
\text { syndrome }\end{array}$ & $4 \mathrm{p} 16$ & $\mathrm{AR}$ & Common atrium, ASD \\
\hline TGFBR2 & Marfan syndrome & $3 p 22$ & $\mathrm{AD}$ & Aortic aneurysm \\
\hline \multicolumn{5}{|c|}{ Extracellular Matrix Protein Genes } \\
\hline FBN1 & Marfan Syndrome & $15 \mathrm{q} 21.1$ & $\mathrm{AD}$ & MVP, aortic root dilatation \\
\hline ELN & Williams Syndrome & $7 \mathrm{q} 11.23$ & $\mathrm{AD}$ & SVAS \\
\hline
\end{tabular}

AD: autosomal dominant, AR: autosomal recessive, AVB: atrioventricular block; HCM: hypertrophic cardiomyopathy, HOS: Holt-Oram syndrome, SVAS: supravalvular aortic stenosis

Table 5. Gene abnormality and contiguous gene syndromes associated with congenital heart anomalies.

\subsubsection{Polygenic / Multifactorial inheritance}

Multifactor inheritance, also known as polygeny, relies on the concept of threshold limit, when the threshold limit of the combined genetic and environmental factors is reached, malformation results. Below the threshold level, the malformation is absent. One common 
key risk is that the babies are genetically oriented towards some level of atypical cardiovascular formation and/or development, together with the exposure to other causative factors. Different stages of cardiac development possess various degrees of vulnerability to environmental factors. Some clues to multifactorial inheritances are a reason for $\mathrm{CHD}$, including a lack of consistent CHD people in the pedigree of the family, and an occasional abnormality with no recognizable pattern in the pedigree of the family.

\subsection{Maternal factors}

Various teratogenic agents have been implicated as the etiologic agents of CHD. For example, women who have insulin-dependent diabetes mellitus, and those who take certain medications, such as acne and epilepsy medication, have a higher risk for having babies with CHD. Women with drug or alcohol abuse also have predisposing risks. The basic biological principle mechanism of teratogens action that cause CHD include susceptible stage of organogenesis development, genetic differences in susceptibility, dose response relationships, and specific actions of the teratogenic agent. The highest degree of embryonic and fetal sensitivity or susceptibility to adverse effects of exposure to teratogens occurs during the first trimester, especially during the $2^{\text {nd }}$ to $8^{\text {th }}$ week of embryonic life. Dose response relationship implies that for each teratogen there is a dose threshold, theoretic dose below which no adverse effects can be observed.

\subsubsection{Maternal health and medical disease}

Certain chronic illnesses in the mother (table 6), such as diabetes, and other viral infections, such as the flu, may contribute to heart defects.

- Maternal diabetes mellitus; The study by Correa et al. found odds ratios for pregestational diabetes mellitus (PGDM) and all cardiac defects was 4.64 (2.87-7.51), while gestational diabetes mellitus (GDM) was associated with cardiac defects found 1.59 (1.27-1.99) (Correa et al., 2008). This excess risk is related to the level of maternal hyperglycemia during the embryonic period. The overall risk of one or more major anomalies is 6 to 7 percent, which is double the risk in the general obstetric population (Wyatt et al., 2005). Congenital heart defects increased in diabetic pregnancy include heterotaxy, TOF, TGA, septal defects, anomalous pulmonary venous return, and various defects causing left or right outflow obstruction (Lisowski et al., 2010; Corrigan et al., 2003; Wren et al., 2003). The possible mechanism is that embryonic hyperglycemia may cause disturbances in metabolism of arachidonic acid, inositol and promote excessive formation of oxygen free radicals which causes mitochondrial damage, and activation of apoptotic pathways.

- Maternal phenylketonuria; One of the most common teratogen of pregnancy complications, when these pregnancies are untreated, $90 \%$ of the offspring suffer microcephaly, mental retardation and increased risk of heart defects through increased blood levels of phenylalanine and phenyl pyruvic acid (Rouse \& Azen, 2004). Frequencies of congenital abnormalities increased with increasing maternal phenylalanine levels. The MPKUCS has demonstrated an increased rate of CHD (7.5\%), the most frequent cardiac defects are TOF, Coarc, PDA, HLH and VSD (Levy et al., 2001). Diet control before conception and during pregnancy reduces the risk of CHD (Matalon et al., 2003; Michals-Matalon et al., 2002). 
- Maternal connective tissue diseases; Connective tissue disease is a group of multisystem disorder, such as systemic lupus erythematosus (SLE), which have been associated with congenital complete atrioventricular heart block in offspring. With regard to maternal anti-Ro and anti-La autoantibodies can transmit from a mother to the fetus, which causes a fetal inflammatory response that damages the AV nodal and myocardial tissue in susceptible fetus' which may result in myocarditis, endocardial fibroelastosis and cardiac arrhythmias (Buyon et al., 2009; Clancy \& Buyon, 2004).

- Maternal rubella; Women who contract rubella during pregnancy have a high risk of having a baby with congenital rubella syndrome (CRS) which will cause effects such as miscarriage, stillbirth, and a series of birth defects. The risk of fetal infection varies according to the time of onset of maternal infection. Infection rates are highest during the first trimester. The most common manifestations of CRS are congenital cataracts, sensorineural deafness, and congenital heart defects (especially PDA). When the heart is targeted, there is direct viral damage to the myocardium, affecting primarily the left atrium and the heart septa, leading to thrombosis, necrosis, and hemorrhage that cause of PDA, PS, and ASD (De Santis et al., 2006; Webster, 1998).

- Maternal febrile illness; Influenza during the first trimester of pregnancy is associated with febrile illness, which appears to cause more right-sided obstructive heart defects, especially TA and PA, some left obstructive defects and VSD (Oster et al., 2011; Tikkanen \& Heinonen, 1991; Yu et al., 2008; Botto et al., 2001). In both hyperthermia and infection there have been documented biological effects on developmental apoptosis pathways. It has been suggested that altered apoptosis may cause birth defects, and apoptosis is known to be involved in cardiac morphogenesis, such as in the development of the cardiac outflow tract.

- Maternal Stress; Intense maternal stress during the periconceptional period was associated with increased risk of delivering infants with certain congenital anomalies particularly with conotruncal heart defects and neural tube defects (Carmichael \& Shaw, 2000; Adams et al., 1989).

- Maternal obesity; Many studies have examined the association between maternal prepregnancy and during pregnant obesity (elevated BMI $>25.0 \mathrm{Kg} / \mathrm{m}^{2}$ ) with $\mathrm{CHD}$ such as ASD, VSD, conotruncal defects and right ventricular outflow tract defects (Cedergren \& Kallen, 2003; Mills et al., 2010; Oddy et al., 2009; Gilboa et al., 2010). Several aspects of such potential associations between obesity and heart defects remain unclear due to studies of obesity and heart defects which are difficult to assess and compare because of the possibility of bias in obesity that may associated with unrecognized diabetes. While some literature found no association between maternal weight and isolated CHDs (Khalil et al., 2008; Watkins \& Botto, 2001).

\subsubsection{Maternal drug and medical use}

Consumption of many drugs, such as thalidomide and isotretinoin, during early gestationcan interfere with the normal cardiogenesis of the fetus. This list of definite and potential human cardiac teratogens was showed in table 6.

\subsubsection{Maternal drugs abuse}

Some studies suggest that drinking alcohol or using cocaine, especially during the pregnancy, can increase the risk of congenital heart defects (table 6). 
- Caffeine; Caffeine can cross the placenta, and the concern that caffeine may causes birth defects prompted the FDA to caution pregnant women to limit their caffeine intake. Today, there is no evidence associating caffeine ingestion during pregnancy and teratogenicity of congenital heart disease (Pejtsik et al., 1992; Linn et al., 1982).

- Alcohol; Maternal alcohol use during pregnancy is associated with fetal alcohol syndrome which comprise a spectrum of abnormal face, growth restriction, central nervous system abnormality and cardiac defects with VSDs occurring most commonly (Pejtsik et al., 1992; Carmichael et al, 2003; Burd et al., 2007; Loser et al., 1992). In Spain, a case-control study by Martinez-Frias et al. reported that a higher risk of developing CHDs was found in the group with the highest-level daily doses of alcohol consumption (the absolute alcohol ingestion was more than 92 gram per day. However, mechanism in teratogenic effect of alcohol on the developing heart malformation is as of now unclear.

- Cocaine; Maternal cocaine ingestion was reported to induce coronary thrombosis in the developing fetal heart leading to formation of a single ventricle, other defects were also reported, such as Ebstein's anomaly, VSD, heterotaxy (Linn et al., 1982; Kueh \& Loffredo, 2002; Lipshultz et al., 1991; Martin \& Khoury, 1992).

- Cigarette Smoking; Smoking during pregnancy enhances the risk of adverse pregnancy outcomes such as low birth weight. The relationship between gestational smoking and congenital heart defects has been studied, however the information is inconclusive. Some studies have reported associations between maternal smoking and ASD, AVSD, TOF (Alverson et al., 2011; Malik et al., 2008; Kallen, 1999). A recent study in Greece found that periconceptional tobacco smoking was associated with increased risk of $\mathrm{CHD}$ in the offspring $(\mathrm{OR}=2.7)$ and has been associated with a quantity of cigarette smoking (Karatza et al., 2011). However, no associations were found (Kallen, 1999) so research on large population-based studies is required to evaluate.

\subsection{Environment or lifestyle factors}

Evidence of teratogenic contamination in certain environments and workplaces is sporadic, albeit environmental factors are a more common cause for multifactorial inheritance CHD. Definitive evidence for the causal relationship between certain exposure and CHD is still unavailable. Available evidence suggests the finding of the higher incidence of CHD babies from women who reside in area with drinking water contaminated by trichloroethylene, dichloroethylene and chromium. While maternal exposure to paint, lacquer, agricultural chemicals, organic solvents, dyes and lead have also been occasionally found statistically associated with CHD. Ingestion of heavy metals and lifetime accumulation of a considerable amount of heavy metals through diet also affects CHD development in babies (table 6).

- Organic Solvents; A few studies reported increased risk of HLH, Coarc, PS, TGA with intact ventricular septum, TOF, TAPVR, non-chromosomal AVSD and Ebstein's anomaly. Other reports of occupational exposure to organic solvents have been associated with an increased risk of VSD (Tikkanen \& Heinonen, 1991, 1992; Shaw et al., 2003). However the precise links are difficult to clarify, because solvent composition varies between different commercial preparations.

- Pesticides \& Other Toxic Substances; A study by Adam et al suggests an association of maternal employment in the agricultural industry with an increased risk of conotruncal defects that suggests a possible association with chemicals used in agriculture (Adams 


\begin{tabular}{|c|c|c|c|}
\hline Risk factor & Common lesion of CHD & $\begin{array}{l}\text { Estimated risk } \\
\text { of CHD (OR) }\end{array}$ & Reference \\
\hline \multicolumn{4}{|l|}{ Maternal health: } \\
\hline $\begin{array}{l}\text { Diabetis mellitus in } \\
\text { pregnancy }\end{array}$ & $\begin{array}{l}\text { Heterotaxy, TOF, TGA, septal defects, } \\
\text { left or right outflow obstruction }\end{array}$ & $4.6-10.0$ & $1-3$ \\
\hline - Phenylketonuria & TOF, COA, PDA, VSD. HLH & $>6$ & 4 \\
\hline - Connective tissue disease & Complete atrioventricular heart block & Increased & 5,6 \\
\hline - Rubella infection & PDA, PS, ASD & Increased & $7-9$ \\
\hline - Febrile illness & Tricuspid or pulmonary atresia, VSD & $1.8-2.8$ & 10 \\
\hline - Stress & Conotruncal heart defects & Increased & 11,12 \\
\hline - Obesity & $\begin{array}{l}\text { Conotruncal heart defects, TAPVR, } \\
\text { HLH, septal defects }\end{array}$ & $1-3$ & $13-16$ \\
\hline \multicolumn{4}{|l|}{ Maternal medical use: } \\
\hline - Lithium & Ebstein's anomaly, MR,TR & 7.7 & 17,18 \\
\hline - Vitamin $A>10,000 \mathrm{IU} / \mathrm{d}$ & Outflow tract defect & increased & 19,20 \\
\hline - Isotretinoin (RoAccutane) & $\begin{array}{l}\text { Overriding aorta, interrupted, } \\
\text { hypoplastic aortic arch, ASD ,VSD }\end{array}$ & increased & 21,22 \\
\hline - Trimethadione & TOF, HLH, TGA, & increased & 23 \\
\hline - Phenytoin & Coarc, PDA,AS, PS & increased & 24 \\
\hline - Valproic acid & Outflow tract, VSD TOF & increased & 25,26 \\
\hline - Coumadin & PDA & increased & 27 \\
\hline - Thalidomide & PS, TGA, TAPVR,VSD, ASD, TA, TOF & increased & 28 \\
\hline - Ibuprofen & TGA, AVSD, VSD & 1.8 & 29 \\
\hline - Naproxen & Any defects & 1.7 & 29 \\
\hline $\begin{array}{l}\text { Trimethoprim } \\
\text {-Sulfonamide }\end{array}$ & Any defects & $2.1-4.8$ & 30 \\
\hline - Sulfasalazine & Any defects & 3.4 & 31 \\
\hline - Nitrofurantoin & HLH, ASD, VSD & 1.6 & 32 \\
\hline $\begin{array}{l}\text { - Angiotensin-converting } \\
\text { Enzyme inhibitors }\end{array}$ & ASD, VSD, PS, PDA & 3.7 & 33 \\
\hline $\begin{array}{l}\text { - Tricyclic / tetracyclic } \\
\text { Antidepressant }\end{array}$ & VSD & 2.2 & 34 \\
\hline - Paroxitine & VSD, ASD & $1.3-1.7$ & 35,36 \\
\hline \multicolumn{4}{|l|}{ Maternal illegal drug: } \\
\hline - Alcohol & VSD & $1.3-1.7$ & $37-40$ \\
\hline - Cigarette Smoking & ASD, AVSD, TOF & $1.0-3.0$ & $41-43$ \\
\hline - Cocaine and Marijuana & $\begin{array}{l}\text { Single ventricle, Ebstein's anomaly, } \\
\text { VSD, heterotaxy }\end{array}$ & Increased & $44-47$ \\
\hline \multicolumn{4}{|l|}{ Environmental: } \\
\hline - Organic Solvents & TGA, HLH, Coarc, TOF, PS & $2.3-3.9$ & $48-50$ \\
\hline - Pesticides & TGA, TAPVR, VSD & Increased & 12 \\
\hline $\begin{array}{l}\text { - Air pollution: } \\
-\mathrm{CO} \\
\text {-NO }\end{array}$ & $\begin{array}{l}\text { VSD, TOF, PS } \\
\text { TOF }\end{array}$ & $\begin{array}{l}1.2-2.6 \\
1.1\end{array}$ & $\begin{array}{l}51,52 \\
51,52\end{array}$ \\
\hline
\end{tabular}

(Ref: ${ }^{1}$ Lisowski et al., 2010; ${ }^{2}$ Corrigan et al., 2009; ${ }^{3}$ Wren et al., 2003; ${ }^{4}$ Rouse \& Azen, 2004; ${ }^{5}$ Buyon et al., 2009; ${ }^{6}$ Clancy \& Buyon, 2004; ${ }^{7}$ Row, 1973 ; ${ }^{8}$ De Santis et al., 2006; ${ }^{9}$ Webster, $1998 ;{ }^{10}$ Botto et al., 2001; ${ }^{11}$ Carmichael \& Shaw, 2000; ${ }^{22}$ Adam et al., 1989; ${ }^{13}$ Cedergren \& Kallen, 2003; ${ }^{14}$ Mills et al., 2010; ${ }^{15}$ Oddy et al., 2009; ${ }^{16}$ Gilboa et al., 2010; ${ }^{17}$ Cohen et al., 1994; ${ }^{18 J}$ Jacobson et al., 1992; ${ }^{19}$ Rothman et al., 1995; ${ }^{20}$ Botto et al., 2001; ${ }^{21}$ Lammer et al., 1985; ${ }^{22}$ Willhite et al., 1986; ${ }^{23}$ Rischbieth, 1979; ${ }^{24} \mathrm{O}^{\prime}$ Brien \& Gilmour-White, 1993; ${ }^{25}$ Sonoda et al., 1993; ${ }^{26}$ Winter et al., 1987; ${ }^{27} \mathrm{Hou}, 2004 ;{ }^{28}$ Smithells \& Newman, 1992; ${ }^{29}$ Ericson \& Kallen, 2001; ${ }^{30}$ Czeizel et al., 2001; ${ }^{31}$ Newman \& Correy, 1983; ${ }^{32}$ Crider et al., 2009; ${ }^{33}$ Cooper et al., 2006; ${ }^{34}$ Kallen \& Otterblad Olausson, 2006; ${ }^{35 B a r-O z ~ e t ~ a l ., ~ 2007 ; ~}{ }^{36}$ Berard et al., 2007; 37 Pejtsil et al., 1992; ${ }^{38}$ Carmichael et al., 2003; ${ }^{39}$ Burd et al., 2007; ${ }^{40}$ Loser et al., 1992; ${ }^{41}$ Alverson et al., 2011; ${ }^{42}$ Malik et al., 1999; ${ }^{43}$ Kallen, 1999; ${ }^{44}$ Linn et al., 1982; ${ }^{45}$ Kuehl \& Loffredo, 2002; ${ }^{46}$ Lipshultz et al., 1991; 47Martin \& Khoury, 1992; 48 Tikkanen \& Heinonen, 1991; ${ }^{49}$ Shaw et al., 2003; ${ }^{50}$ Tikkanen et al., 1992; ${ }^{51}$ Gilboa et al., 2005; ${ }^{52}$ Dadvand et al., 2011)

Table 6. Risk factors that are known or believed to be associated with the congenital heart defects. 
et al., 1989). In the Baltimore-Washington Infant Study (BWIS), potential exposure to herbicides and rodenticides was associated with an increased risk of TGA, while potential exposure to pesticides was associated with TAPVR and VSD. A case-control study of various end-product uses reported an increased risk of conotruncal defects with maternal reports of exposure to insecticides (Shaw et al., 1999).

- Air Pollution; Ambient air pollution such carbon monoxide (CO), nitric oxide (NO), ozone $\left(\mathrm{O}_{3}\right)$, and sulfur dioxide $\left(\mathrm{SO}_{2}\right)$ may cause $\mathrm{CHD}$ dependent on pollutant levels (Ritz et al., 2002; Rankin et al., 2009). A study by Gilboa et al, observed positive associations between carbon monoxide and isolated ASD, TOF, particulate matter $<10$ $\mu \mathrm{m}$ in diameter and isolated ASD as well as between ozone and VSD (Gilboa et al., 2005). From a study by Dadvand et al, exposure to $\mathrm{CO}$ and $\mathrm{NO}$ has been associated with ventricular septal defect and cardiac septa malformations. $\mathrm{CO}$ was also associated with congenital pulmonary valve stenosis and NO was associated TOF (Dadvand et al., 2011). Further studies are also required to clarify if air pollution exposure influences the risk for CHD.

- Maternal Home Tap Water Consumption; It has a positive association between a mother's consumption of home tap water during the first trimester of pregnancy and cardiac anomalies. This was unrelated to water contamination, mother's race, or her educational level (Shaw et al., 1990).

- Waste Sites; Many of the recent studies about possible increased risk of CHD in communities situated near hazardous waste sites are inconsistent (Croen et al., 1997) and may not ultimately prove to be causal.

- Ionizing Radiation; there are few reports on possible associations of CHD with maternal exposure to ionizing radiation in occupational settings or as part of medical or dental evaluations. Studies found no clear evidence of any association. Further studies are also required to clarify the precise relationship between these factors and CHD.

\section{Prevention}

Excluding genetic counseling, the genetic disorder cannot be protected against; simple guidelines to pregnant mothers for prevention of CHD in their newborns are good diet, physical activity, lifestyle, environments and occupation that the parents should discuss with their primary care provider or obstetrician. Women of childbearing age also should obtain prenatal care, including testing for diabetes and past rubella immunization, they should also discuss any medication use with their obstetrician; and should avoid contact with ill people, especially those with rubella or influenza. Women of childbearing age should take 400 micrograms of folic acid on a daily basis starting before pregnancy, which can reduce congenital heart and neural tube defects, and should avoid certain types of behaviors such as exposure to organic solvents, smoking and heavy alcohol use. If a woman has no immunity to rubella, she should get vaccinated prior to pregnancy. Preconception care and appropriate dietary management for women with phenylketonuria should be an important strategy. Detection and appropriate management of diabetes before and during pregnancy should be an important step for reducing risk of CHD in offspring. Avoidance of medications that are suspected to cause congenital defects, including congenital heart disease, should be taken, and the medications should have warnings about that risk to allow mothers and physicians to make informed decisions about the risks and benefits of the use of the medication during pregnancy. Recommendations also are possible for screening for 
possible cardiac defects using fetal echocardiography during pregnancy when warranted by reports of prenatal maternal illnesses or exposures. The need for screening any individual should be made on an individual basis from the type, likelihood, and level of potential exposure, as well as the time of gestation during which it occurred. This decision typically will be made as a result of the obstetrical history. Because congenital heart defects represent some of the more prevalent birth defects, that result in significant lifelong morbidity, and are an important cause of mortality attributed to birth defects, the development of effective prevention interventions is paramount from a public health perspective.

\section{Conclusion}

The number of patients, both children and adults, with CHD has continued to rise. The most common reasons for $\mathrm{CHD}$ are associated with multiple factors. Epidemiology studies reveal underestimated cases of $\mathrm{CHD}$, and together with the etiology the studies help to define potential risk factors for CHD. The epidemiology and etiology of CHD also help prioritize the areas needed for intervention and additional regulations the public health officers may impose. Patients and parents of babies with CHD must understand the significance of routine medical checkups, which can be accomplished though an effective transition program and collaboration among healthcare providers.

\section{Acknowledgement}

The authors thank Sarah Hof and Randall Jones for their supports in proofreading.

\section{References}

Adams, MM.; Mulinare, J. \& Dooley, K. (1989). Risk factors for conotruncal cardiac defects in Atlanta. Journal of the American College of Cardiology, Vol.14, No.2, (August 1989), pp. 432-442, ISSN 0735-1097

Akazawa, H. \& Komuro, I. (2005). Cardiac transcription factor Csx/Nkx2-5: Its role in cardiac development and diseases. Pharmacology \& therapeutics, Vol.107, No.2, (Ausgust 2005), pp. 252-268, ISSN 1879-016X

Akdeniz, C.; Odemis, E.; Erdem, A. \& Celebi, A. (2009). Double outlet right ventricle and aortopulmonary window in a patient with Cornelia de Lange syndrome: a novel association. Genetic counseling, Vol.20, No.2, pp. 161-166, ISSN 1015-8146

Alabdulgader, AAA. (2006). Congenital heart disease in Saudi Arabia: current epidemiology and future projects. Eastern Mediterranean Health Journal, Vol.12, No.2, pp. 157-167, ISSN 1020-3397

Alverson, CJ.; Strickland, MJ.; Gilboa, SM. \& Correa, A. (2011). Maternal smoking and congenital heart defects in the Baltimore-Washington Infant Study. Pediatrics, Vol.127, No.3, (March 2011), pp. e647-e653, ISSN 1098-4275

Ali, BR.; Akawi, NA.; Chedid, F.; Bakir, M.; Ur Rehman, M.; Rahmani, A. \& Al-Gazali, L. (2010). Molecular and clinical analysis of Ellis-van Creveld syndrome in the United Arab Emirates. BMC Medical Genetics, Vol.11, (Febuary 2010), pp. 33, ISSN 14712350

Amro, K. (2009). Pattern of Congenital Heart Disease in Jordan. European Journal of General Medicine, Vol.6, No.3, pp. 161-165, ISSN 1304-3897 
Arrington, CB.; Nightengale, D.; Lowichik, A.; Rosenthal, ET.; Christian-Ritter, K. \& Viskochil, DH. (2006). Pathologic and molecular analysis in a family with rare mixed supravalvar aortic and pulmonic stenosis. Pediatric and Devopmental Pathology, Vol.9, No.4, (July-August 2006), pp. 297-306, ISSN 1615-5742

Ballesta Martinez, MJ.; Guillen Navarro, E.; Lopez Exposito, I.; Bafalliu Vidal, JA.; Domingo Jimenez, R.; Guia Torrent, JM.; Robles Sanchez, F. \& Sanchez Solis de Querol, M. (2008). [Review of 22 patients with 22q11.2 deletion syndrome: phenotype spectrum]. Anales de pediatria (Barcelona, Spain: 2003), Vol.69, No.4, (October 2008), pp. 304-310, ISSN 1695-9531

Bar-Oz, B.; Einarson, T.; Einarson, A.; Boskovic, R.; O'Brien, L.; Malm, H.; Berard, A. \& Koren, G. (2007). Paroxetine and congenital malformations: meta-Analysis and consideration of potential confounding factors. Clinical Therapeutics, Vol.29, No.5, (May 2007), pp. 918-926, ISSN 0149-2918

Barisic, I.; Tokic, V.; Loane, M.; Bianchi, F.; Calolari, E.; Game, E.; Wellesley, D. \& Dolk, H. (2008). Descriptive epidemiology of Cornelia de Lange syndrome in Europe. American Journal of Medical Genetics Part A, Vol.146A, No.1, (January 2008), pp. 5159, ISSN 1552-4833

Basson, CT.; Huang, T.; Lin, RC.; Bachinsky, DR.; Weremowicz, S.; Vaglio, A.; Bruzone, R.; Quadrelli, R.; Lerone, M.; Romeo, G.; Silengo, M.; Pereira, A.; Krieger, J.; Mesquita, SF.; Kamisago, M.; Morton, CC.; Pierpont, ME.; Muller, CW.; Seidman, JG. \& Seidman, CE. (1999). Different TBX5 interactions in heart and limb defined by HoltOram syndrome mutations. Proceedings of the National Academy of Sciencs of the United States of America, Vol.96, No.6, (March 1999), pp. 2919-2924, ISSN 1091-6490

Battaglia, A.; Carey, JC.; Cederholm, P.; Viskochil, DH.; Brothman, AR. \& Galasso, C. (1999). Natural history of Wolf-Hirschhorn syndrome: experience with 15 cases. Pediatrics, Vol.103, No.4 Pt 1, (April 1999), pp. 830-836, ISSN 1098-4275

Berard, A.; Ramos, E.; Rey, E.; Blais, L.; St-Andre, M. \& Oraichi, D. (2007). First trimester exposure to paroxetine and risk of cardiac malformations in infants: the importance of dosage. Birth Defects Research. Part B, Developmental and Reproductive Toxicology, Vol.80, No.1, (Febuary 2007), pp. 18-27, ISSN 1542-9733

Berends, MJ.; Tan-Sindhunata, G.; Leegte, B. \& van Essen, AJ. (2001). Phenotypic variability of Cat-Eye syndrome. Genetic counseling, Vol.12, No.1, pp. 23-34, ISSN 1015-8146

Bernier, PL.; Stefanescu, A.; Samoukovic, G. \& Tchervenkov, CI. (2010). The Challenge of Congenital Heart diease Worldwide: Epidemiologic and Demographic Facts. Pediatric Cardiac Surgery Annual, pp. 26-34, ISSN $1092-9126$

Boneva, RS.; Botto, LD.; Moore, CA.; Yang, Q, Correa, A. \& Erickson, JD. (2001). Mortality Associated With Congenital Heart Defects in the United States: Trends and Racial Disprities, 1979-1997. Circulation, Vol.103, (May 2001), pp. 2376-2381, ISSN 15244539

Borzouee, M. \& Jannati, M. (2008). Distribution and Characteristecs of the Heart Disease in Pediatric Age Group in Southern Iran. Iranian Cardiovascular Research Journal, Vol.2, No.1, pp. 48-51, ISSN 1735-8868

Botto, LD.; Correa, A. \& Erickson, JD. (2001). Racial and Temporal Variations in The Prevalence of Heart Defects. Pediatrics, Vol.107, No.3, (March 2001), pp. 1-8, ISSN $1098-4275$ 
Botto, LD. \& Correa, A. (2003). Decreasing the burden of congenital heart anomalies: an epidemiologic evaluation of risk factors and survival. Progress in Pediatric Cardiology, Vol.18, pp. 111-121, ISSN 1058-9813

Botto, LD.; Lynberg, MC. \& Erickson, JD. (2001). Congenital heart defects, maternal febrile illness, and multivitamin use: a population-based study. Epidemiology, Vol.12, No.5, (September 2001), pp. 485-490, ISSN 1531-5487

Botto, LD.; Loffredo, C.; Scanlon, KS.; Ferencz, C.; Khoury, MJ.; David Wilson, P. \& Correa, A. (2001). Vitamin A and cardiac outflow tract defects. Epidemiology, Vol.12, No.5, (September 2001), pp. 491-496, ISSN 1531-5487

Bound, JP. \& Logan, WF. (1977). Incidence of congenital heart disease in Blackpool 19571971. British Heart Journal, Vol.39, pp. 445-450, ISSN 0007-0769

Brautbar, A.; LeMaire, SA.; Franco, LM.; Coselli, JS.; Milewicz, DM. \& Belmont, JW. FBN1 mutations in patients with descending thoracic aortic dissections. American Journal of Medical Genetics Part A, Vol.152A, No.2, (Febuary 2010), pp. 413-416, ISSN 15524833

Brown, ML.; Dearani, JA. \& Burkhart, HM. (2009). The adult with congenital disease: medical and surgical considerations for management. Current Opinion in Pediatrics, Vol.21, pp. 561-564, ISSN 1040-8703

Burd, L.; Deal, E.; Rios, R.; Adickes, E.; Wynne, J. \& Klug, MG. (2007). Congenital heart defects and fetal alcohol spectrum disorders. Congenital Heart Disease, Vol.2, No.4, (August 2007), pp. 250-255, ISSN 1747-0803

Buyon, JP.; Clancy, RM. \& Friedman, DM. (2009). Autoimmune associated congenital heart block: integration of clinical and research clues in the management of the maternal / foetal dyad at risk. Journal of Internal Medicine, Vol.265, No.6, (June 2009), pp. 653662, ISSN 1365-1796

Ceizel, A.; Pornoi, A.; Peterffy, E. \& Tarcal, E. (1982). Study of children of parents operated on for congenital cardiovascular malformations. British Heart Journal, Vol.47, No.3, (March, 2001), pp. 290-293, ISSN 0007-0769

Calmont, A.; Ivins, S.; Van Bueren, KL.; Papangeli, I.; Kyriakopoulou, V.; Andrews, WD.; Matin, JF.; Moon, AM.; Illingworth, EA.; Basson, A. \& Scambler, PJ. (2009). Tbx1 controls cardiac neural crest cell migration during arch artery development by regulating Gbx2 expression in the pharyngeal ectoderm. Development, Vol.136, No.18, (September 2009), pp. 3173-3183, ISSN 1461-7072

Carmichael, SL. \& Shaw, GM. (2000). Maternal life event stress and congenital anomalies. Epidemiology, Vol.11. No.1, (January 2000), pp. 30-35, ISSN 1531-5487

Carmichael, SL.; Shaw, GM.; Yang, W. \& Lammer, EJ. (2003). Maternal periconceptional alcohol consumption and risk for conotruncal heart defects. Birth Defects Reserch Part A. Clinical and Molecular Teratology, Vol.67, No.10, (October 2003), pp. 875-878, ISSN 1542-0760

Casey, B.; Devoto, M.; Jones, KL. \& Ballabio, A. (1993). Mapping a gene for familial situs abnormalities to human chromosome Xq24-q27.1. Nature Genetics, Vol.5, No.4, (December 1993), pp. 403-407, ISSN 1546-1718

Cedergren, MI. \& Kallen, BA. (2003). Maternal obesity and infant heart defects. Obesity Research, Vol.11, No.3, (September 2003), pp. 1065-1071, ISSN 1550-8528

Clancy, RM. \& Buyon, JP. (2004). Autoimmune-associated congenital heart block: dissecting the cascade from immunologic insult to relentless fibrosis. The anatomicla record. 
Part A, Discoveries in molecular, cellular, and evolutionary biology, Vol.280, No.2, (October 2004), pp. 1027-1035, ISSN 1552-4884

Cody, JD.; Ghidoni, PD.; DuPont, BR.; Hale, DE.; Hilsenbeck, SG.; Stratton, RF.; Hoffman, DS.; Muller, S.; Schaub, RL.; Leach, RJ. \& Kaye, CI. (1999).. Congenital anomalies and anthropometry of 42 individuals with deletions of chromosome 18q. American Journal of Medical Genetics, Vol.85. No.5, (August 1999), pp. 455-462, ISSN 0148-7299

Cohen, LS.; Friedman, JM.; Jefferson, JW.; Johnson, EM. \& Weiner, ML. (1994). A reevaluation of risk of in utero exposure to lithium. Journal of the American Medical Association, Vol.271, No.2, (January 1994), pp. 146-150, ISSN 1538-3598

Colliton, RP.; Bason, L.; Lu, FM.; Piccoli, DA.; Krantz, ID. \& Spinner, NB. (2001). Mutation analysis of Jagged1 (JAG1) in Alagille syndrome patients. Human Mutation, Vol.17, No.2, (Febuary 2001), pp. 151-152, ISSN 1098-1004

Cooper, WO.; Hernandez-Diaz, S.; Arbogast, PG.; Dudley, JA.; Dyer, S.; Gideon, PS.; Hall, K. \& Ray, WA. (2006). Major congenital malformations after first-trimester exposure to ACE inhibitors. The New England Journal of Medicine, Vol.354, No.23, (June 2006), pp. 2443-2451, ISSN 1533-4406

Correa, A.; Gilboa, SM.; Besser, LM.; Botto, LD.; Moore, CA.; Hobbs, CA.; Cleves, MA.; Reihle-Colarusso, TJ.; Waller, DK. \& Reece, EA. (2008). Diabetes mellitus and birth defects. American Journal of Obestetrics and Gynecology, Vol.199, No.3, (September 2008), pp. e1-e9, ISSN 1097-6886

Corrigan, N.; Brazil, DP. \& McAuliffe, F. (2009). Fetal cardiac effects of maternal hyperglycemia during pregnancy. Birth Defects Research Part A. Clinical and Molecular Teratology, Vol.85, No.6, (June 2009), pp. 523-530, ISSN 1542-0760

Crider, KS.; Cleves, MA.; Reefhuis, J.; Berry, RJ.; Hobbs, CA. \& Hu, DJ. (2009). Antibacterial medication use during pregnancy and risk of birth defects: National Birth Defects Prevention Study. Archives of Pediatrics and Adolescent Medicine, Vol.163, No.11, (November 2009), pp. 978-985, ISSN 1538-3628

Croen, LA.; Shaw, GM.; Sanbonmatsu, L.; Selvin, S. \& Buffler, PA. (1997). Maternal residential proximity to hazardous waste sites and risk for selected congenital malformations. Epidemiology, Vol.8, No.4, (July 1997), pp. 347-354, ISSN 1531-5487

Czeizel, AE.; Rockenbauer, M.; Sorensen, HT. \& Olsen, J. (2001). The teratogenic risk of trimethoprim-sulfonamides: a population based case-control study. Reproductive Toxicology, Vol.15, No.6, (November-December 2001), pp. 637-646, ISSN 1873-1708

Dadvand, P.; Rankin, J.; Shitley, MDF.; Rushton, S. \& Pless-Mulloli, T. (2008). Descriptive epidemiology of congenital heart disease in Northern England. Paediatric and Perinatal Epidemiology, Vol.23, pp. 58-65, ISSN 1365-3016

Dadvand, P.; Rankin, J.; Rushton, S. \& Pless-Mulloli, T. (2011). Association between maternal exposure to ambient air pollution and congenital heart disease: A registerbased spatiotemporal analysis. American Journal of Epidemiology, Vol.173, No.2, (January 2011), pp. 171-182, ISSN 0002-9262

De Backer, J. (2009). Cardiovascular characteristics in Marfan syndrome and their relation to the genotype. Verhandelingen-Koninklijke Academie voor Geneeskunde van Belgie, Vol.71, No.6, pp. 335-371, ISSN 0302-6469

De Luca, A.; Sarkozy, A.; Ferese, R.; Consoli, F.; Lepri, F.; Dentici, ML.; Vergara, P.; De Zorzi, A.; Versacci, P.; Digilio, MC.; Marino, B. \& Dallapiccola, B. (2010). New mutations 
in ZFPM2/FOG2 gene in tetralogy of Fallot and double outlet right ventricle. Clinical Genetics, Vol.3, pp. 1-7, ISSN 1399-0004

De Santis, M.; Cavaliere, AF.; Straface, G. \& Caruso, A. (2006). Rubella infection in pregnancy. Reproductive Toxicology, Vol.21, No.4, (May 2006), pp. 390-398, ISSN 1873-1708

Devriendt, K.; Matthijs, G.; Van Dael, R.; Gewillig, M.; Eyskens, B.; Hjalgrim, H.; Dolmer, B.; McGaughran, J.; Brondum-Nielsen, K.; Marynen, P.; Fryns, JP. \& Vermeesch, JR. (1999). Delineation of the critical deletion region for congenital heart defects, on chromosome 8p23.1. American Journal of Heman Genetics, Vol.64. No.4, (April 1999), pp. 1119-1126, ISSN 0002-9297

Dickinson, DF.; Arnold, R. \& Wilkinson, JL. (1981). Congenital heart disease among 160480 liveborn children in Liverpool 1960 to 1969 Implications for surgical treatment. British Heart Journal, Vol.46, pp. 55-62, ISSN 0007-0769

Dietz, HC.; Pyeritz, RE.; Hall, BD.; Cadle, RG.; Hamosh, A.; Schwartz, J.; Meyers, DA. \& Francomano, CA. (1991). The Marfan syndrome locus: confirmation of assignment to chromosome 15 and identification of tightly linked markers at 15q15-q21.3. Genomics, Vol.9, No.2, (Febuary 1991), pp. 355-361, ISSN 0888-6717

Digilio, MC.; Marino, B.; Giannotti, A.; Di Donato, R. \& Dallapiccola, B. (2000). Heterotaxy with left atrial isomerism in a patient with deletion 18p. American Journal of Medical Genetics, Vol.94, No.3, (September 2000), pp. 198-200, ISSN 0148-7299

Digilio, MC.; Angioni, A.; Giannotti, A.; Dallapiccola, B. \& Marino, B. (2003). Truncus arteriosus and duplication 8q. American Journal of Medical Genetics Part A, Vol.121A, No.1, (August 2003), pp. 79-81, ISSN 1552-4833

Dolk, H. \& Loane, M. (March, 2009). EUROCAT Steering Committee: Congenital heart defects in Europe: 2000-2005, April 2011, Available from: http://eurocat.bio-medical.co.uk/content/Special-Report-CHD.pdf

Dolk, H.; Loane, M. \& Game, E. (2010). The prevalence of congenital anomalies in Europe. Advances in Experimental Medicine and Biology, Vol.686, pp. 349-364, ISSN 0065-2598

Douchin, S.; Rossignol, AM.; Klein, SK.; Siche, JP.; Baguet, JP. \& Bost, M. (2000). [Heart malformations and vascular complications associated with Turner's syndrome. Prospective study of 26 patients]. Archives des maladies du Coeur et des vaisseaux, Vol.93, No.5, (May 2000), pp. 565-570, ISSN 0003-9683

Edelman, EA.; Girirajan, S.; Finucane, B.; Patel, PI.; Lupski, JR.; Smith, AC. \& Elsea, SH. (2007). Gender, genotype, and phenotype differences in Smith-Magenis syndrome: a meta-analysis of 105 cases. Clinical Genetics, Vol.71, No.6, (June 2007), pp. 540-550, ISSN 0009-9163

Elliott, DA.; Kirk, EP.; Yeoh, T.; Chandar, S.; McKenzie, F.; Taylor, P.; Grossfeld, P.; Fatkin, D.; Jones, O.; Hayes, P.; Feneley, M. \& Harvey, RP. (2003). Cardiac homeobox gene NKX2-5 mutations and congenital heart disease: associations with atrial septal defect and hypoplastic left heart syndrome. Journal of the American College of Cardiology, Vol.41, No.11, (June 2003), pp. 2072-2076, ISSN 0735-1097

El-Rassy, I.; Bou-Abdallah, J.; Al-Ghadban, S.; Bitar, F. \& Nemer, G. (2008). Absence of NOTCH2 and Hey2 mutations in a familial Alagille syndrome case with a novel frameshift mutation in JAG1. American Journal of Medical Genetics Part A, Vol.146, No.7, (April 2008), pp. 937-939, ISSN 1552-4833 
Ericson, A. \& Kallen, BA. (2001). Nonsteroidal anti-inflammatory drugs in early pregnancy. Reproductive Toxicology, Vol.15, No.4, (July-August 2001), pp. 371-375, ISSN 18731708

Eronen, M.; Peippo, M.; Hiippala, A.; Raatikka, M.; Arvio, M.; Johansson, R. \& Kahkonen, M. (2002). Cardiovascular manifestations in 75 patients with Williams syndrome. Journal of Medical Genetics, Vol.39, No.8, (August 2002), pp. 554-558, ISSN 1468-6244

Fan, C.; Liu, M. \& Wang, Q. (2003). Functional analysis of TBX5 missense mutations associated with Holt-Oram syndrome. Journal of Boiological Chemistry, Vol.278, No.10, (March 2003), pp. 8780-8785, ISSN 0021-9258

Faria, MH.; Rabenhorst, SH.; Pereira, AC. \& Krieger, JE. (2008). A novel TBX5 missense mutation (V263M) in a family with atrial septal defects and postaxial hexodactyly. Intenal Journal of Cardiology, Vol.130, No.1, (October 2008), pp. 30-35, ISSN 01671718

Fatema, NN.; Chowdhury, RB. \& Chowdhury, L. (2008). Incidence of Congenital Heart Disease among Hospital Live Birth in a Tertiar Hospital of Bangladesh. Cardiovascular Journal, Vol.1, No.1, pp. 14-20, ISSN 2071-0917

Ferencz, C.; Rubin, JD.; McCarter, RJ.; Brenner, JI.; Neil, CA.; Perry, LW.; Hepner, SI. \& Downing, JW. (1985). Congenital heart disease: prevalence at birth. The BaltimoreWashington Infant Study. American Journal of Epidemiology, Vol.121, No.1, pp. 3116, ISSN0002-9262

Ferencz, C.; Boughman, JA.; Neill, CA.; Brenner, JI. \& Perry, LW. (1989). Congenital cardiovascular malformations: questions on inheritance. Baltimore-Washington Infant Study Group. Journal of the American College of Cardiology, Vol.14, No.3, pp. 756-763, ISSN 0735-1097

Ferrero, GB.; Biamino, E.; Sorasio, L.; Banaudi, E.; Peruzzi, L.; Forzano, S.; Di Cantogno, LV. \& Silengo, MC. (2007). Presenting phenotype and clinical evaluation in a cohort of 22 Williams-Beuren syndrome patients. European Journal of Medical Genetics, Vol.50, No.5, (September-October 2007), pp. 327-337, ISSN 1769-7212

Fixler, DE.; Pastor, P.; Chamberlin, M.; Sigman, E. \& Eifler, CW. (1990). Trend in Congenital Heart Disease in Dallas County Births. 1971-1984. Circulation, Vol.81, No.1, (January 1990), pp. 137-142, ISSN 1524-4539

Garg, V.; Kathiriya, IS.; Barnes, R.; Schluterman, MK.; King, IN.; Butler, CA.; Rothrock, CR.; Eapen, RS.; Hirayama-Yamada, K.; Joo, K.; Matsuka, R.; Cohen, JC. \& Ssrivastava, D. (2003). GATA4 mutations cause human congenital heart defects and reveal an interaction with TBX5. Nature, Vol.424, No.6947, (July 2003), pp. 443-447, ISSN 1476-4687

Garg, V.; Muth, AN.; Ransom, JF.; Schluterman, MK.; Barnes, R.; King, IN.; Grossfeld, PD. \& Srivastva, D. (2005). Mutations in NOTCH1 cause aortic valve disease. Nature, Vol.437, No.7056, (September 2005), pp. 270-274, ISSN 1476-4687

Garne, E.; Stoll, C. \& Clementi, M. (2001). Evaluation of prenatal diagnosis of congenital heart disease by ultrasound: experience from 20 European registries. Ultrasound in Obstetrics \& Gynecology, Vol.17, (May 2001), pp. 386-391, ISSN 1469-0705

Giltay, JC.; Bokma, JA.; de France, H. \& Beemer, FA. (1998). VSD, hypospadias and normal psychomotor development in a patient with inv dup 8(13-q21.2). Clinical Genetics, Vol.53, No.1, (January 1998), pp. 74-78, ISSN 0009-9163 
Gittenberger-de Groot, AC; Bartelings, MM; Deruiter, MC \& Poelmann, RR. (2005). Basics of cardiac development for the understanding of congenital heart malformations. Pediatric Research, Vol.57, No.2, (February 2005), pp. 169-176, ISSN 0031-3998

Germanakis, I. \& Sifakis, S. (2006). The Impact of Fetal Echocardiography on the Prevalence of Liveborn Congenital Heart Disease. Pediatric Cardiology, Vol. 27, No.4, pp. 465472, ISSN 1432-1971

Gilboa, SM.;, Correa, A.; Botto, LD.; Rasmussen, SA.; Waller, DK.; Hobbs, CA.; Cleves, MA. \& Riehle-Colarusso, TJ. (2010). Association between prepregnancy body mass index and congenital heart defects. American Journal of Obstetrics \& Gynecology, Vol.202, No.1, (January 2010), pp. e1-e10, ISSN 1097-6868

Gilboa, SM.; Mendola, P.; Olshan, AF.; Langlois, PH.; Savitz, DA.; Loomis, D.; Herring, AH. \& Fixler, DE. (2005). Relation between ambient air quality and selected birth defects, seven county study, Texas, 1997-2000. American Journal of Epidemiology, Vol.162, No.3, (August 2005), pp. 238-252, ISSN 0002-9262

Goldmuntz, E.; Bamford, R.; Karkera, JD.; dela Cruz, J.; Roessler, E. \& Muenke, M. (2002). CFC1 mutations in patients with transposition of the great arteries and doubleoutlet right ventricle. American Journal of Human Genetics, Vol.70, No.3, (March 2002), pp. 776-780, ISSN 0002-9297

Green, EK.; Priestley, MD.; Waters, J.; Maliszewska, C.; Latif, F. \& Maher, ER. (2000). Detailed mapping of a congenital heart disease gene in chromosome 3p25. Journal of Medical Genetics, Vol.37, No.8, (August 2000), pp. 581-587, ISSN 1468-6244

Grinberg, I. \& Millen, KJ. (2005). The ZIC gene family in development and disease. Clinical Genetics, Vol.67, No.4, (April 2005), pp. 290-296, ISSN 0009-9163

Grossfeld, PD.; Mattina, T.; Lai, Z.; Favier, R.; Jones, KL.; Cotter, F. \&Jones, C. (2004). The 11q terminal deletion disorder: a prospective study of 110 cases. American Journal of Medical Genetics Part A, Vol.129A, No.1, (August 2004), pp. 51-61, ISSN 1552-4833

Guo, Y.; Shen, J.; Yuan, L.; Li, F.; Wang, J. \& Sun, K. (2010). Novel CRELD1 gene mutations in patients with atrioventricular septal defect. World Journal of Pediatrics, Vol.6, No.4, (November 2010), pp. 348-52, ISSN 1708-8569

Heritage, ML.; MacMillan, JC. \& Anderson, GJ. (2002). DHPLC mutation analysis of Jagged1 (JAG1) reveals six novel mutations in Australian alagille syndrome patients. Human Molecular Genetics, Vol.20, No.6, (December 2002), pp. 481, ISSN 0964-6906

Hilger-Eversheim, K.; Moser, M.; Schorle, H. \& Buettner, R. (2000). Regulatory roles of AP-2 transcription factors in vertebrate development, apoptosis and cell-cycle control. Gene, Vol.260, No.1-2, (December 2000), pp. 1-12, ISSN 1769-7212

Hills, C.; Moller, JH.; Finkelstein, M.; Lohr, J. \& Schimmenti, L. (2006). Cri du chat syndrome and congenital heart disease: a review of previously reported cases and presentation of an additional 21 cases from the Pediatric Cardiac Care Consortium. Pediatrics, Vol.117, No.5, (May 2006), pp. e924-e927, ISSN 1098-9163

Hoffman, JIE. \& Christianson, R. (1978). Congenital heart disease in a cohort of 19502 births with long-term follow-up. The American journal of cardiology, Vol.42, No.4, (October 1978), pp. 641-647, ISSN 0002-9149

Hoffman, JIE. \& Kaplan, S. (2002). The Incidence of Congenital Heart Disease. Journal of the American College of Cardiology, Vol.39, No.12, (June 2002), pp. 1890-1900, ISSN 07351097 
Hou, JW. (2004). Fetal warfarin syndrome. Chang Gung Medical Journal, Vol.27, No.9, (September 2004), pp. 691-695, ISSN 2072-0939

Huang, T.; Lin, AE.; Cox, GF.; Golden, WL.; Feldman, GL.; Ute, M.; Schrander-Stumpel, C.; Kamisago, M. \& Vermeulen, SJ. (2002). Cardiac phenotypes in chromosome 4qsyndrome with and without a deletion of the dHAND gene. Genetics in Medicine, Vol.4. No.6, (November-December 2002), pp. 464-467, ISSN 1530-0366

Jacobson, SJ.; Jones, K.; Johnson, K.; Ceolin, L.; Kaur, P.; Sahn, D.; Donnenfeld, AE.; Rieder, M, Santelli, R. \& Smythe, J. (1992). Prospective multicentre study of pregnancy outcome after lithium exposure during first trimester. Lancet, Vol.339, No.8792, (Febuary 1992), pp. 530-533, ISSN 1474-547X

Jamieson, CR.; van der Burgt, I.; Brady, AF.; van Reen, M.; Elsawi, MM.; Hol, F.; Jeffery, S.; Patton, MA. \& Mariman, E. (1994). Mapping a gene for Noonan syndrome to the long arm of chromosome 12. Nature Genetics, Vol.8, No.4, (December 1994), pp. 357360, ISSN 1546-1718

Jerome, LA. \& Papaioannou, VE. (2001). DiGeorge syndrome phenotype in mice mutant for the T-box gene, Tbx1. Nature Genetics, Vol.27, No.3, (March 2001), pp. 286-291, ISSN 1546-1718

Jongmans, M.; Sistermans, EA.; Rikken, A.; Nillesen, WM.; Tamminga, R.; Patton, M.; Maier, EM.; Tartaqlia, M.; Noordam, K. \& van der Burgt, I. (2005). Genotypic and phenotypic characterization of Noonan syndrome: new data and review of the literature. American Journal of Medical Genetics Part A, Vol.134A, No.2, (April 2005), pp. 165-170, ISSN 1552-4833

Kallen, B. \& Otterblad Olausson, P. (2006). Antidepressant drugs during pregnancy and infant congenital heart defect. Reproductive Toxicology, Vol.21, No.3, (April 2006), pp. 221-222, ISSN 1873-1708

Kallen, K. (1999). Maternal smoking and congenital heart defects. European Journal of Epidemiology, Vol.15, No.8, (September 1999), pp. 731-737, ISSN 0393-2990

Khalil, HS.; Saleh, AM. \& Subhani, SN. (2008). Maternal obesity and neonatal congenital cardiovascular defects. International Journal of Gynaecolgy and Obstetrics, Vol.102, No.3, (September 2008), pp. 232-236, ISSN 1879-3479

Karatza, AA.; Giannakopoulos, I.; Dassios, TG.; Belavgenis, G.; Mantagos, SP.; Varvarigou AA. (2011). Periconceptional tobacco smoking and Xisolated congenital heart defects in the neonatal period. Internal Journal of Cardiology, Vol.105, No.2, (May 2011), pp. 295-299, ISSN0167-5273

Kenny, D. (2008). Long-term outcome of the child with congenital heart disease. Paediatrics and child health, Vol.19, No.1, pp. 37-42, ISSN 1205-7088

Khalil, A.; Aggarwal, R.; Thirupuram, S. \& Arora, R. (1994). INCIDENCE OF CONGENITAL HEART DISEASE AMONG HOSPITAL LIVE BIRTHS IN INDIA. INDIAN PEDIATRICS, Vol.31, (May 1994), pp. 519-527 ISSN 0019-6061

Knowles, R.; Griebsch, I.; Dezateux, C. \& Brown, J. (2005). Newborn screening for congenital heart defects: a systemic review and cost-effectiveness analysis. Health Technology Assessment, Vol.9, No.44, pp. 1-6, ISSN 1366-5278

Komuro, I. \& Izumo, S. (1993). Csx: a murine homeobox-containing gene specifically expressed in the developing heart. Proceedings of the NationalAcedemy of Sciencs of the United States of America, Vol.90, No.17, (Septeber 1993), pp. 8145-8149, ISSN 10916490 
Kuehl, KS. \& Loffredo, C. (2002). Risk factors for heart disease associated with abnormal sidedness. Teratology, Vol.66, No.5, (November 2002), pp. 242-248, ISSN 0040-3709

Lammer, EJ.; Chen, DT.; Hoar, RM.; Agnish, ND.; Benke, PJ.; Braun, JT.; Curry, CJ.; Fernhoff, PM.; Grix, AW Jr. \& Lott, IT. (1985). Retinoic acid embryopathy. The New England Journal of Medicine, Vol.13, No.14, (October 1985), pp. 837-841, ISSN 1533-4406

Levy, HL.; Guldberg, P.; Guttler, F.; Hanley, WB.; Matalon, R.; Rouse, BM.; Trefz, F.; Azen, C.; Allred, EN.; de la Cruz, F. \& Koch, R. (2001). Congenital heart disease in maternal phenylketonuria: report from the Maternal PKU Collaborative Study. Pediatric Research, Vol.49, No.5, (May 2001), pp. 636-642, ISSN 0031-3998

Lichiardopol, C. \& Mota, M. (2004). Cardiovascular risk factors in Turner's syndrome. Romanian Journal of Internal Medicine, Vol.42, No.2, pp. 371-379, ISSN 1220-4749

Li, D.; Yu, J.; Gu, F.; Pang, X.; Ma, X.; Li, R.; Liu, N. \& Ma, X. (2008). The roles of two novel FBN1 gene mutations in the genotype-phenotype correlations of Marfan syndrome and ectopia lentis patients with marfanoid habitus. Genetic Testing, Vol.12, No.2, (June 2008), pp. 325-330, ISSN 1557-7473

Li, QY.; Newbury-Ecob, RA.; Terrett, JA.; Wilson, DI.; Curtis, AR.; Yi, CH.; Gebuhr, T.; Bullen, PJ.; Robson, SC.; Strachan, T.; Bonnet, D.; Lyonnet, S.; Young, ID.; Raeburn, JA.; Buckler, AJ.; Law, DJ. \& Brook, JD. (1997). Holt-Oram syndrome is caused by mutations in TBX5, a member of the Brachyury (T) gene family. Nature Genetics, Vol.15, No.1, (January 1997), pp. 21-29, ISSN 1546-1718

Lillehei, CW.; Dewall, RA.; Read, RC.; Warden, HE. \& Varco, RL. (1956). Direct Vision Intracardiac Surgery in Man Using a Simple, Disposable Artificial Oxygenator. DISEASES of the CHEST, Vol.29, No.1, January 1956, pp. 1-8, ISSN 0096-0217

Lin, HY.; Lin, SP.; Chen, YJ.; Hsu, CH.; Kao, HA.; Chen, MR.; Hung, HY.; Ho, CS.; Chang, JH.; Huang, FY.; Tsai, TC.; Lin, DS. \& Chan, WY. (2007). Clinical characteristics and survival of trisomy 13 in a medical center in Taiwan, 1985-2004. Pediatrics International, Vol.49, No.3, (June 2007), pp. 380-386, ISSN 1442-200X

Lindinger, A.; Schwedler, G. \& Hense, HW. (2010). Prevalence of Congenital Heart Defect in Newborns in Germany: Results of the First Registration Year of the PAN Study (July 2006 to June 2007). Klinische Padiatrie, Vol.222, pp. 321-326, ISSN 0300-8630

Linn, S.; Schoenbaum, SC.; Monson, RR.; Rosner, B.; Stubblefield, PG. \& Ryan, KJ. (1982). No association between coffee consumption and adverse outcomes of pregnancy. The New England Journal of Medicine, Vol.306, No.3, (January 1982), pp. 141-145, ISSN 1533-4406

Linnankivi, T.; Tienari, P.; Somer, M.; Kahkonen, M.; Lonnqvist, T.; Valanne, L. \& Pigko, H. (2006).. 18q deletions: clinical, molecular, and brain MRI findings of 14 individuals. American Journal of Medical Genetics Part A, Vol.140, No.4, (Febuary 2006), pp. 331339, ISSN 1552-4833

Lipshultz, SE.; Frassica, JJ. \& Orav, EJ. (1991). Cardiovascular abnormalities in infants prenatally exposed to cocaine. The Journal of Pediatrics, Vol.118, No.1, (January 1991), pp. 44-51, ISSN 1097-6833

Lisowski, LA.; Verheijen, PM.; Copel, JA.; Kleinman, CS.; Wassink, S.; Visser, GH. \& Meijboom, EJ. (2010). Congenital heart disease in pregnancies complicated by maternal diabetes mellitus. An international clinical collaboration, literature review, and meta-analysis. Herz, Vol.35, No.1, (January 2010), pp. 19-26, ISSN 09461299 
Lizarraga, MA.; Mintegui, S.; Sanchez Echaniz, J.; Galdeano, JM.; Pastor, E. \& Cabrera, A. (1991). [Heart malformations in trisomy 13 and trisomy 18]. Revista Espanola de Cardiologia, Vol.44, No.9, (November 1991), pp. 605-610, ISSN 0300-8932

Loeys, BL.; Schwarze, U.; Holm, T.; Callewaert, BL.; Thomas, GH.; Pannu, H.; De Backer, JF.; Oswald, GL.; Symoens, S.; Manouvier, S.; Roberts, AE.; Faravelli, F.; Greco, MA.; Pyeritz, RE.; Milewic, DM.; Coucke, PJ.; Cameron, DE.; Braverman, AC.; Byers, PH.; De Paepe, AM. \& Dietz, HC. (2006). Aneurysm syndromes caused by mutations in the TGF-beta receptor. The New England Journal of Medicine, Vol.355, No.8, (August 2006), pp. 788-798, ISSN 1533-4406

Loomes, KM.; Underkoffler, LA.; Morabito, J.; Gottlieb, S.; Piccoli, DA.; Spinner, NB.; Baldwin, HS. \& Oakey, RJ. (1999). The expression of Jagged1 in the developing mammalian heart correlates with cardiovascular disease in Alagille syndrome. Human Molecular Genetics, Vol.8, No.13, (December 1999), pp. 2442-2449, ISSN 09646906

Loser, H.; Pfefferkorn, JR. \& Themann, H. (1992). [Alcohol in pregnancy and fetal heart damage]. Klinische Padiatrie, Vol.204, No.5, (September-October 1992), pp. 335-339, ISSN 0300-8630

Majnener, A.; Limperopoulos, C.; Shevell, M.; Rohlicek, C.; Rosenblatt, B. \& Tchervenkov, C. (2008). Developmental and Functional Outcomes at School Entry in Children with Congenital Heart Defects. The Journal of Pediatrics, Vol.153, No.1, (July 2008), pp. 5560 ISSN 0022-3476

Malik, S.; Cleves, MA.; Honein, MA.; Romitti, PA.; Botto, LD.; Yang, S. \& Hobbs, CA. (2008). Maternal smoking and congenital heart defects. Pediatrics, Vol.121, No.4, (April 2008), pp. e810-e816, ISSN 1098-4275

Mani, A.; Radhakrishnan, J.; Farhi, A.; Carew, KS.; Warnes, CA.; Nelson-Williams, C.; Day, RW.; Pober, B.; State, MW. \& Lifton, RP. (2005). Syndromic patent ductus arteriosus: evidence for haploinsufficient TFAP2B mutations and identification of a linked sleep disorder. Proceedings of the National Academy of Sciencs of the United States of America, Vol.102, No.8, (Febuary 2005), pp. 2975-2979, ISSN 1091-6490

Marelli, AJ.; Mackie, AS.; Ionescu-Ittu, R.; Rahme, E. \& Pilote, L. (2007). Congenital Heart Disease in the General Population: Changing Prevalence and Age Distribution. Circulation, Vol.115, No.2, (January 2007), pp. 163-172, ISSN 1524-4539

Martin, ML. \& Khoury, MJ. (1992). Cocaine and single ventricle: a population study. Teratology, Vol.46, No.3, (September 1992), pp. 267-270, ISSN 0040-3709

Matalon, KM.; Acosta, PB. \& Azen, C. (2003). Role of nutrition in pregnancy with phenylketonuria and birth defects. Pediatrics, Vol.112, No.6 Pt 2, (December 2003), pp. 1534-1536, ISSN 1098-9163

Matsuoka, R.; Matsuyama, S.; Yamamoto, Y.; Kuroki, Y. \& Matsui, I. (1981). Trisomy 18q. A case report and review of karyotyope-phenotype correlations. Human Genetics, Vol.57, No.1, pp. 78-82, ISSN 0340-6717

Mattina, T.; Perrotta, CS. \& Grossfeld, P. (2009). Jacobsen syndrome. Orphanet Journal of Rare Disease, Vol.4, pp. 9, ISSN 1750-1172

Mazzanti, L. \& Cacciari, E. (1998). Congenital heart disease in patients with Turner's syndrome. Italian Study Group for Turner Syndrome (ISGTS). The Journal of pediatrics, Vol.133, No.5, (November 1998), pp. 688-698, ISSN 1097-6833 
McDaniell, R.; Warthen, DM.; Sanchez-Lara, PA.; Pai, A.; Krantz, ID.; Piccoli, DA. \& Spinner, NB. (2006). NOTCH2 mutations cause Alagille syndrome, a heterogeneous disorder of the NOTCH signaling pathway. American Journal of Human Genetics, Vol.79, No.1, (July 2006), pp. 169-173, ISSN 0002-9297

McElhinney, DB.; Geiger, E.; Blinder, J.; Benson, DW. \& Goldmuntz, E. (2003). NKX2.5 mutations in patients with congenital heart disease. Journal of American College of Cardiology, Vol.42, No.9, (November 2003), pp. 1650-1655, ISSN 0735-1097

McElhinney, DB.; Krantz, ID.; Bason, L.; Piccoli, DA.; Emerick, KM.; Spinner, NB. \& Goldmuntz, E. (2002). Analysis of cardiovascular phenotype and genotypephenotype correlation in individuals with a JAG1 mutation and/or Alagille syndrome. Circulation, Vol.106, No.20, (November 2002), pp. 2567-2574, ISSN 00077322

McFadden, DG. \& Olson, EN. (2002). Heart development: learning from mistakes. Current Option in Genetics \& Development. Vol.12, No.3, (June 2002), pp. 328-335, ISSN 0959437X

McKellar, SH.; Tester, DJ.; Yagubyan, M.; Majumdar, R.; Ackerman, MJ. \& Sundt, TM. (2007). 3rd. Novel NOTCH1 mutations in patients with bicuspid aortic valve disease and thoracic aortic aneurysms Journal of Thoracic and Cardiovascular Surgery, Vol.134, No.2, (August 2007), pp. 290-296, ISSN 0022-5223.

Mettler, BA. \& Peeler, BB. (2009). Congenital Heart Disease: Surgery in Adult. Surgical Clinics of North America, Vo.189, pp. 1021-1032, ISSN 0039-6109

Micale, L.; Turturo, MG.; Fusco, C.; Augello, B.; Jurado, LA.; Izzi, C.; Digilio, MC.; Milani, D.; Lapi, E.; Zelante, L. \& Merla, G. (2010). Identification and characterization of seven novel mutations of elastin gene in a cohort of patients affected by supravalvular aortic stenosis. European Journal of Human Genetics, Vol.18, No.3, (March 2010), pp. 317-323, ISSN 1476-5438

Michals-Matalon, K.; Platt, LD.; Acosta, PP.; Azen, C. \& Walla, CA. (2002). Nutrient intake and congenital heart defects in maternal phenylketonuria. American Journal of Obestetrics and Gynecology, Vol.187, No.2, (August 2002), pp. 441-444, ISSN 10976868

Mills, JL.; Troendle, J.; Conley, MR.; Carter, T. \& Druschel, CM. (2010). Maternal obesity and congenital heart defects: a population-based study. The American Journal of Clinical Nutrition, Vol.91, No.6, (June 2010), pp. 1543-1549, ISSN 1938-3207

Mitchell, SC.; Korones, SB. \& Berendes, HW. (1971). Congenital Heart Disease in 56,109 Birhts: Incidence and Natural History. Circulation, Vol.43, (March 1971), pp. 323332, ISSN 1524-4539

Mohamed, SA.; Aherrahrou, Z.; Liptau, H.; Erasmi, AW.; Hagemann, C.; Wrobel, S.; Borzym, K.; Schunkert, H.; Sievers, HH. \& Erdmann, J. (2006). Novel missense mutations (p.T596M and p.P1797H) in NOTCH1 in patients with bicuspid aortic valve. Biochemical and Biophysical Research Communications, Vol.345, No.4, (July 2006), pp. 1460-1465, ISSN 0006-291X

Moons, P.; Pinxten, S.; Dedroog, D.; Deyk, KV.; Gewillig, M.; Hilderson, D. \& Budts, W. (2009). Expectations and Experiences of Adolescents with Congenital Heart Disease on Being Transferred from Pediatric Cardiology to an Adult Congenital Heart Disease Program. Journal of Adolescent Health, Vol.44, No.4, (April, 2009), pp. 307412, ISSN 1054-139X 
Morris, CD. (2004). Lessons from epidemiology for the care of women with congenital heart disease. Progress in Pediatric Cardiology, Vol.19, pp. 5-13, ISSN 1058-9813

Movahhedian, HR.; Kane, HA.; Borgaonkar, D.; McDermott, M. \& Septimus, S. (1991). Heart disease associated with deletion of the short arm of chromosome 18. Delaware Medical Journal, Vol.63, No.5, (May 1991), pp. 285-289, ISSN 0011-7781

Muncke, N.; Jung, C.; Rudiger, H.; Ulmer, H.; Roeth, R.; Hubert, A.; Goldmuntz, E.; Driscoll, D.; Goodship, J.; Schon, K. \& Rappold, G. (2003). Missense mutations and gene interruption in PROSIT240, a novel TRAP240-like gene, in patients with congenital heart defect (transposition of the great arteries). Circulation, Vol.108,No.23, (December 2003), pp. 2843-2850, ISSN 0009-7322

Musewe, NN.; Alexander, DJ.; Teshima, I.; Smallhorn, JF. \& Freedom, RM. (1990). Echocardiographic evaluation of the spectrum of cardiac anomalies associated with trisomy 13 and trisomy 18. Journal of the American College of Cardiology, Vol.15, No.3, (March 1990), pp. 673-677, ISSN 0735-1097

Neptune, ER.; Frischmeyer, PA.; Arking, DE.; Myers, L.; Bunton, TE.; Gayraud, B.; Ramirez, F.; Sakai, LY. \& Dietz, HC. (2003). Dysregulation of TGF-beta activation contributes to pathogenesis in Marfan syndrome. Nature Genetics, Vol.33, No.3, (March 2003), pp. 407-411, ISSN 1546-1718

Newman, NM. \& Correy, JF. (1983). Possible teratogenicity of sulphasalazine. The Medical Journal of Australia, Vol.1, No.11, (May 1983), pp. 528-529, ISSN 1326-5377

O'Brien, MD. \& Gilmour-White, S. (1993). Epilepsy and pregnancy. BMJ, Vol.307, No.6902, (August 1993), pp. 492-495, ISSN 1468-5833

Oddy, WH.; De Klerk, NH.; Miller, M.; Payne, J. \& Bower, C. (2009). Association of maternal pre-pregnancy weight with birth defects: evidence from a case-control study in Western Australia. The Australian \& Nezeland Journal of Obstetrics E Gynaecology, Vol.49, No.1, (Febuary 2009), pp. 11-15, ISSN 1497-828X

Oster, ME.; Riehle-Colarusso, T.; Alverson, CJ. \& Correa, A. (2011). Associations between maternal Fever and influenza and congenital heart defects. The Journal of Pediatrics, Vol.158, No.6, (June 2011), pp. 990-995, ISSN 1097-6833

Ozcelik, C.; Bit-Avragim, N.; Panek, A.; Gaio, U.; Geier, C.; Lange, PE.; Dietz, R.; Posch, MG.; Perrot, A. \& Stiller, B. (2006). Mutations in the EGF-CFC gene cryptic are an infrequent cause of congenital heart disease. Pediatric Cardiology, Vol.27, No.6, (November-December 2006), pp. 695-698, ISSN 1432-1971

Paladini, D.; Tartaglione,, A.; Agangi, A.; Teodoro, A.; Forleo, F.; Borghese, A. \& Martinelli, P. (2000). The association between congenital heart disease and Down syndrome in prenatal life. Ultrasound in Obstetrics E Gynecology, Vol.15, No.2, (February 2000), pp. 104-108, ISSN 1469-0705

Pejtsik, B.; Pinter, J.; Horvath, M. \& Hadnagy, J. (1992). [Relationship between congenital heart disease and various factors affecting pregnancy]. Orvosi Hetilap, Vol.133, No.3, (January 1992), pp. 155-158, ISSN 1788-6120

Petersen, S.; Peto, V. \& Rayner, M. (2003). Congenital heart disease statistics 2003, 19 April 2011, Available from: http: www.heratstats.org

Pizzuti, A.; Sarkozy, A.; Newton, AL.; Conti, E.; Flex, E.; Digilio, MC.; Amati, F.; Gianni, D.; Tandoi, C.; Marino, B.; Crossley, M. \& Dallapiccola, B. (2003). Mutations of ZFPM2/FOG2 gene in sporadic cases of tetralogy of Fallot. Human Genetics, Vol.22, No.5, (November 2003), pp. 372-377, ISSN 1098-1004 
Polymeropoulos, MH.; Ide, SE.; Wright, M.; Goodship, J.; Weissenbach, J.; Pyeritz, RE.; Da Silva, EO.; Ortiz De Luna, RI. \& Francomano, CA. (1996). The gene for the Ellis-van Creveld syndrome is located on chromosome 4p16. Genomics, Vol.35, No.1, (July 1996), pp. 1-5, ISSN 0888-7543

Potocki, L.; Shaw, CJ.; Stankiewicz, P. \& Lupski, JR. (2003). Variability in clinical phenotype despite common chromosomal deletion in Smith-Magenis syndrome [del(17)(p11.2p11.2)]. Genetics in Medicine, Vol.5, No.6, (November-December 2003), pp. 430-434, ISSN 1530-0366

Poprawski, K.; Michalski, M.; Lawniczak, M. \& Lacka, K. (2009). Cardiovascular abnormalities in patients with Turner syndrome according to Karyotype: own experience and literature review. Polskie archiwum medycyny wewnetrznej, Vol.119, No.7-8, (July-August 2009), pp. 453-460, ISSN 0032-3772

Reid, GJ.; Irvine, MJ.; McCrindle, BW.; Sananes, R.; Ritvo, PG.; Siu, SC. \& Webb, GD. (2004). Prevalence and Correlates of Successful Transfer From Pediatric to Adult Health Care Among a Cohort of Young Adults With Complex Congenital Heart Defects. Pediatrics, Vol.113, No.3, (March 2004), pp. e197-e205, ISSN 1098-4275

Rankin, J.; Chadwick, T.; Natarajan, M.; Howel, D.; Pearce, MS. \& Pless-Mulloli, T. (2009). Maternal exposure to ambient air pollutants and risk of congenital anomalies. Environmental Research, Vol.109, No.2, pp. 181-187, ISSN 0013-9351

Reid-Lombardo, KM. \& Petersen, GM. (2010). Understanding genetic epidermiologic association studies Part 1: fundamentals. Surgery, Vol.147, No.4, (April 2010), pp. 469-474, ISSN

Reller, MD.; Stricklland, MJ.; Richle-Colarusso, T.; Mahle, WT. \& Correa, A. (2008). Prevalence of Congenital Heart Defect in Metropolitan Atlanta, 1998-2005. The Journal of Pediatrics, Vol.153, No.6, (December 2008), pp. 803-813, ISSN 00022-3476

Report of the British Cardiac Society Working Party. (2002). Grown-up congenital heart $(\mathrm{GUCH})$ disease: current needs and provision of service for adolescents and adults with congenital heart disease in the UK. Heart, Vol.88, No.1, pp. i1-i4, ISSN 13556037

Rischbieth, RH. (1979). Troxidone (trimethadione) embryopathy: case report with reveiw of the literature. Clinical and Experimental Neurology, Vol.16, pp. 251-256, ISSN 01966383

Ritz, B.; Yu, F.; Fruin, S.; Chapa, G.; Shaw, GM. \& Harris, JA. (2002). Ambient air pollution and risk of birth defects in Southern California. American Journal of Epidemiology, Vol.155, No.1, (January 2002), pp. 17-25, ISSN 0002-9262

Robicsek, F.; Thubrikar, MJ.; Cook, JW. \& Fowler, B. (2004). The congenitally bicuspid aortic valve: how does it function? Why does it fail? The Annals of Thoracic Surgery, Vol.77, No.1, (January 2004), pp. 177-185, ISSN 0003-4975

Robinson, SW.; Morris, CD.; Goldmuntz, E.; Reller, MD.; Jones, MA.; Steiner, RD. \& Maslen, CL. (2003). Missense mutations in CRELD1 are associated with cardiac atrioventricular septal defects. American Journal of Human Genetics, Vol.72, No.4, (April 2003), pp. 1047-1052, ISSN 0002-9297

Rodriguez-Revenga, L.; Badenas, C.; Carrio, A. \& Mila, M. (2005). Elastin mutation screening in a group of patients affected by vascular abnormalities. Pediatric Cardiology, Vol.26, No.6, (November-December 2005), pp. 827-831, ISSN 1432-1971 
Romana-Zelekha, O.; Hirsh, R.; Blieden, L.; Green, MS. \& Shohat, T. (2001). The risk for congenital heart defects in offspring of individuals with congenital heart defects. Clinical Genetics, Vol.59, (May 2001), pp. 325-329 ISSN 1399-0004

Roisas, PR.; Sijstermans, JM.; Theunissen, PM.; Pulles-Heintberger, CF.; De Die-Smulders, CE.; Engelen, JJ. \& Van Der Meer, SB. (2001). Phenotypic variability of the cat eye syndrome. Case report and review of the literature. Genetic counseling, Vol.12, No.3, pp. 273-282, ISSN 1015-8146

Rose, V.; Boyd, ARJ. \& Ashton, TE. (1964). Incidence of Heart Disease in Children in the City of Toronto. The Canadian Medical Association Journal, Vol.91, No.3, (July 1964), pp. 95-100, ISSN 1488-2329

Roskes, EJ.; Boughman, JA.; Schwartz, S. \& Cohen, MM. (1990). Congenital cardiovascular malformations (CCVM) and structural chromosome abnormalities: a report of 9 cases and literature review. Cinical Genetics, Vol.38, No.3, (September 1990), pp. 198-210, ISSN 0009-9163

Rothman, KJ.; Moore, LL.; Singer, MR.; Nguyen, US.; Mannino, S. \& Milunsky, A. (1995). Teratogenicity of high vitamin A intake. The New England Journal of Medicine, Vol.333, No.21, (November 1995), pp. 1369-1373, ISSN 1533-4406

Rouse, B. \& Azen, C. (2004). Effect of high maternal blood phenylalanine on offspring congenital anomalies and developmental outcome at ages 4 and 6 years: the importance of strict dietary control preconception and throughout pregnancy. The Journal of Pediatrics, Vol.44, No.2, (Febuary 2004), pp. 235-239, ISSN 1097-6833

Ruiz-Perez, VL.; Ide, SE.; Strom, TM.; Lorenz, B.; Wilson, D.; Woods, K.; King, L.; Francomano, C.; Freisinger, P.; Spranger, S.; Marino, B.; Dallapiccola, B.; Wright, M.; Meitinger, T.; Polymeropoulos, MH. \& Goodship, J. (2000). Mutations in a new gene in Ellis-van Creveld syndrome and Weyers acrodental dysostosis. Natur Genetics, Vol.24, No.3, (March 2000), pp. 283-286, ISSN 1546-1718

Satoda, M.; Zhao, F.; Diaz, GA.; Burn, J.; Goodship, J.; Davidson, HR.; Pierpont, ME. \& Gelb, BD. (2000). Mutations in TFAP2B cause Char syndrome, a familial form of patent ductus arteriosus. Nature Genetics, Vol.25, No.1, (May 2000), pp. 42-46, ISSN 15461718

Sarkozy, A.; Conti, E.; Seripa, D.; Digilio, MC.; Grifone, N.; Tandoi, C.; Fazio, VM.; Di Ciommo, V.; Marino, B.; Pizzuh, A. \& Dallapiccola, B. (2003). Correlation between PTPN11 gene mutations and congenital heart defects in Noonan and LEOPARD syndromes. Journal of Medical Genetics, Vol.40, No.9, (September 2003), pp. 704-708, ISSN 1468-6244

Sayasathid, J.; Tantiwongkosri, K. \& Somboonna, N. (2009). Unrecognied Congenital Heart Disease among Thai Children. Journal of The Medical Association of Thailand, Vol.92, No.3, (March 2009), pp. 356-359, ISSN 0125-2208

Sayasathid, J.; Supachokchaipattanna, P.; Pipatvech, K.; Sukonpan, K.; Somboonna, N. \& Pannarunothai, S. (2010). The prevalence of unrecognized congenital heart disease among healthy elementary school students in northern Thailand. Asian Biomedicine, Vol.4, No.1, (February 2010), pp. 171-175, ISSN 1905-7415

Selicomi, A.; Colli, AM.; Passarini, A.; Milani, D.; Cereda, A.; Cerutti, M.; Maitz, S.; Alloni, V.; Salvini, L.; Galli, MA.; Ghiglia, S.; Salice, P. \& Danzi, GB. (2009). Analysis of congenital heart defects in 87 consecutive patients with Brachmann-de Lange 
syndrome. American Journal of Medical Genetics Part A, Vol.149A, No.6, (June 2009), pp. 1268-1272, ISSN 1552-4833

Serrano-Martin, MM.; Martinez-Aedo, MJ.; Tartaglia, M. \& Lopez-Siguero, JP. (2008). [SOS1 mutation: a new cause of Noonan syndrome]. Anales de Pediatria (Barcelona, Spain: 2003), Vol.68, No.4, (April 2008), pp. 365-368, ISSN 1695-9531

Shaw, GM.; Nelson, V.; Iovannisci, DM.; Finnell, RH. \& Lammer, EJ. (2003). Maternal occupational chemical exposures and biotransformation genotypes as risk factors for selected congenital anomalies. American Journal of Epidemiology, Vol.157, No.6, (March 2003), pp. 475-484, ISSN 0002-9262

Shaw, GM.; Swan, SH.; Harris, JA. \& Malcoe, LH. (1990). Maternal water consumption during pregnancy and congenital cardiac anomalies. Epidemiology, Vol.1, No.3, (May 1990), pp. 206-211, ISSN 1531-5487

Shaw, GM.; Wasserman, CR.; O'Malley, CD.; Nelson, V. \& Jackson, RJ. (1999). Maternal pesticide exposure from multiple sources and selected congenital anomalies. Epidemiology, Vol.10, No.1, (January 1999), pp. 60-66, ISSN 1531-5487

Shprintzen, RJ. (2008). Velo-cardio-facial syndrome: 30 Years of study. Development Disabilities Research Reviews, Vol.14, No.1, pp. 3-10, ISSN 1080-4013

Shuib, S.; McMullan, D.; Rattenberry, E.; Barber, RM.; Rahman, F.; Zatyka, M.; Chapman, C.; Macdonald, F.; Latif, F.; Davison, V. \& Maher, ER. (2009). Microarray based analysis of 3p25-p26 deletions (3p- syndrome). American Journal of Medical Genetics Part A, Vol.149A, No.10, (October 2009), pp. 2099-2105, ISSN 1552-4833

Smithells, RW. \& Newman, CG. (1992). Recognition of thalidomide defects. Journal of Medical Genetics, Vol.29, No.10, (October 1992), pp. 716-723, ISSN 1468-6244

Singh, KK.; Rommel, K.; Mishra, A.; Karck, M.; Haverich, A.; Schmidtke, J. \& ArslanKirchner, M. (2006). TGFBR1 and TGFBR2 mutations in patients with features of Marfan syndrome and Loeys-Dietz syndrome. Human Mutation, Vol.27, No.8, (August 2006), pp. 770-777, ISSN 1098-1004

Sonoda, T.; Ohdo, S.; Ohba, K.; Okishima, T. \& Hayakawa, K. (1993). Sodium valproateinduced cardiovascular abnormalities in the Jcl:ICR mouse fetus: peak sensitivity of gestational day and dose-dependent effect. Teratology, Vol.48, No.2, (August 1993), pp. 127-132, ISSN 0040-3709

Stallmeyer, B.; Fenge, H.; Nowak-Gottl, U. \& Schulze-Bahr, E. (2010). Mutational spectrum in the cardiac transcription factor gene NKX2.5 (CSX) associated with congenital heart disease. Cinical Genetics, Vol.78, No.6, (December 2010), pp. 533-540, ISSN 0009-9163

Strehle, EM. \& Bantock, HM. (2003). The phenotype of patients with 4q-syndrome. Genetic Counseling, Vol.14, No.2, pp. 195-205, ISSN 1015-8146

Tan, KB. \& Yeo, GS. (2009). Pattern of Turner syndrome in Singapore (1999-2004). Singapore Medical Journal, Vol.50, No.6, (June 2009), pp. 587-590, ISSN 0037-5675

Tennstedt, C., Chaoui, R.; Korner, H. \& Dietel, M. (1999). Spectrum of congenital heart defects and extracardiac malformations associated with chromosomal abnormalities: results of a seven year necropsy study. Heart, Vol.82, No.1, (July 1999), pp. 34-39, ISSN 1468-201X

Tevosian, SG.; Deconinck, AE.; Tanaka, M.; Schinke, M.; Litovsky, SH.; Izumo, S.; Fujiwara, Y. \& Orkin, SH. (2000). FOG-2, a cofactor for GATA transcription factors, is 
essential for heart morphogenesis and development of coronary vessels from epicardium. Cell, Vol.101, No.7, (June 2000), pp. 729-739, ISSN 0092-8674

Thangaratinam, S.; Daniels, J.; Ewer, AK.; Zamora, J. \& Khan, K. (2007). Accuracy of pulse oximetry in screening for congenital disease in asymptomatic newborns: a systematic review. Archives of Disease in Childhood - Fetal and Neonatal Edition, Vol.92, (May, 2007), pp. F176-F180, ISSN 1468-2052

Tikkanen, J. \& Heinonen, OP. (1991). Maternal hyperthermia during pregnancy and cardiovascular malformations in the offspring. European Journal of Epidemiology, Vol.7, No.6, (November 1991), pp. 628-635, ISSN 0393-2990

Tikkanen, J. \& Heinonen, OP. (1991). Risk factors for ventricular septal defect in Finland. Public Health, Vol.105, No.2, (March 1991), pp. 99-112, ISSN 0033-3506

Tikkanen, J. \& Heinonen, OP. (1992). Risk factors for conal malformations of the heart. European Journal of Epidemiology, Vol.8, No.1, (January 1992), pp. 48-57, ISSN 03932990

Toko, H.; Zhu, W.; Takimoto, E.; Shiojima, I.; Hiroi, Y.; Zou, Y.; Oka, T.; Akazawa, H.; Mizukami, M.; Sakamoto, M.; Terasaki, F.; Kitaura, Y.; Takano, H.; Nagai, T.; Nagai, R. \& Komuro, I. (2002). Csx/Nkx2-5 is required for homeostasis and survival of cardiac myocytes in the adult heart. Journal of Biological Chemistry, Vol.227, No.27, (July 2002), pp. 24735-24743, ISSN 0021-9258

Tomita-Mitchell, A.; Maslen, CL.; Morris, CD.; Garg, V. \& Goldmuntz, E. (2007). GATA4 sequence variants in patients with congenital heart disease. Journal of Medical Genetics, Vol.44, No.12, (December 2007), pp. 779-783, ISSN 1468-7212

Tompson, SW.; Ruiz-Perez, VL.; Blair, HJ.; Barton, S.; Navarro, V.; Robson, JL.; Wright, MJ. \& Goodship, JA. (2007). Sequencing EVC and EVC2 identifies mutations in twothirds of Ellis-van Creveld syndrome patients. Human Genetics, Vol.120, No.5, (January 2007), pp. 663-670, ISSN 0340-6717

Tsai, CH.; Van Dyke, DL. \&, Feldman, GL. (1999). Child with velocardiofacial syndrome and del (4)(q34.2): another critical region associated with a velocardiofacial syndromelike phenotype. American Journal of Medical Genetics Part A, Vol.82, No.4, (Febuary 1999), pp. 336-339, ISSN 0148-7299

Van Esch, H.; Groenen, P.; Fryns, JP.; Van de Ven, W. \& Devriendt, K. (1999). The phenotypic spectrum of the 10p deletion syndrome versus the classical DiGeorge syndrome. Genetic Counseling, Vol.10, No.1, pp. 59-65, ISSN 1015-8146

Van Praagh, S.; Truman, T.; Firpo, A.; Bano-Rodrigo, A.; Freied, R.; McManus, B.; Engle, MA. \& Van Praagh, R. (1989). Cardiac malformation in trisomy-18: a study of 41 postmortem cases. Journal of the American College of Cardiology, Vol.13, No.7, (June 1989), pp. 1586-1597, ISSN 1558-3597

Wacker, A.; Kaemmerer, H.; Hollweek, R.; Hauser, M.; Deutsch, MA.; Brodherr, H.; Eicken, A. \& Hess, J. (2005). Outcome of operated and unoperated adults with congenital cardiac disease lost to follow-up for more than five years. American Journal of Cardiology, Vol.95, No.6, (March 2005), pp. 776-779, ISSN 0002-9149

Wang, NK.; Shen, CT. \& Lin, MS. (2007). Results of Echocardiographic Screening in 10,000 Newborns. Acta Paediatric Taiwan, Vol.48, No.1, pp. 7-9, ISSN 1608-8115

Wat, MJ.; Shchelochkov, OA.; Holder, AM.; Breman, AM.; Dagli, A.; Bacino, C.; Scaglia, F.; Zori, RT.; Cheung, SW.; Scott, DA. \& Kang, SHL. (2009). Chromosome 8p23.1 deletions as a cause of complex congenital heart defects and diaphragmatic hernia. 
American Journal of Medical Genetics Part A, Vol. 149A, No.8, (August 2009), pp. 1661-1677, ISSN 1552-4833

Watkins, ML. \& Botto, LD. (2001). Maternal prepregnancy weight and congenital heart defects in offspring. Epidemiology, Vol.12, No.4, (July 2001), pp. 439-446, ISSN 15315487

Webster, WS. (1998). Teratogen update: congenital rubella. Teratology, Vol.58, No.1, (July 1998), pp. 13-23, ISSN 0040-3709

Webb, CL.; Jenkin, KJ.; Parpawich, PP.; Bolger, AF.; Conner, RM.; Allen, HD. \& Barst, RJ. (2002). Collaborative Care for Adults With Congenital Heart Disease. Circulation, Vol.105, No.23, (May 2002), pp. 2318-2323, ISSN 1524-4539

Weijerman, ME.; van Furth, AM.; van der Mooren, MD.; van Weissenbruch, MM.; Rammeloo, L. \& Broers, CJ. (2010). Prevalence of congenital heart defects and persistent pulmonary hypertension of the neonate with Down syndrome. European Journal of Pediatrics, Vol.169, No.10, (October 2010), pp. 1195-1199, ISSN 1432-1076

Willhite, CC.; Hill, RM. \& Irving, DW. (1986). Isotretinoin-induced craniofacial malformations in humans and hamsters. Journal of Craniofacial Genetics and Development Biology - Supplement, Vol.2, pp. 193-209, ISSN 0890-6661

Wilson, GN.; Baker, DL.; Schau, J. \& Paker, J. (1984). Cat eye syndrome owing to tetrasomy 22pter leads to q11. Journal of Medical Genetics, Vol.21, No.1, (February 1984), pp. 60 63, ISSN 1468-6244

Winter, RM.; Donnai, D.; Burn, J. \& Tucker, SM. (1987). Fetal valproate syndrome: is there a recognisable phenotype? Journal of Medical Genetics, Vol.24, No.11, (November 1987), pp. 692-695, ISSN 1468-6244

Wren, C.; Birrell, G. \& Hawthorne, G. (2003). Cardiovascular malformations in infants of diabetic mothers. Heart, Vol89, No.10, (October 2003), pp. 1217-1220, ISSN 13556037

Wu, MH.; Chen, HC.; Lu, CW.; Wang, JK.; Huang, SC. \& Huang, SK. (2010). Prevalence of Congenital Heart Disease at Live Birth in Taiwan. The Journal of Pediatrics, Vol.156, No.5, (May 2010). pp. 782-785, ISSN 0022-3476

Wyatt, JW.; Frias, JL.; Hoyme, HE.; Jovanovic, L.; Kaaja, R.; Brown, F.; Garg, S.; Lee-Parritz, A.; Seely, EW.; Kerr, L.; Mattoo, V. \& Tan, M. (2005). Congenital anomaly rate in offspring of mothers with diabetes treated with insulin lispro during pregnancy. Diabetic Medicine, Vol.22, No.6, (June 2005), pp. 803-807, ISSN 1464-5491

Xin, N.; Qiu, GR.; Gong, LG.; Xu, XY. \& Sun, KL.(2009). [The mechanism of TBX5 abnormal expression in simple congenital heart disease]. Yi Chuan. 2009 Apr;31(4):374-80. YiChuan, Vol.31, No.4, (April 2009), pp. 374-380, ISSN 0253-9772

Xu, H.; Morishima, M.; Wylie, JN.; Schwartz, RJ.; Bruneau, BG.; Lindsay, EA. \& Baldini, A. (2004). Tbx1 has a dual role in the morphogenesis of the cardiac outflow tract. Development, Vol.131, No.13, (July 2004), pp. 97-101, ISSN 1461-7072

Yagi, H.; Furutani, Y.; Hamada, H.; Sasaki, T.; Asakawa, S.; Minoshima, S.; Ichida, F.; Joo, K.; Kimura, M.; Imamura, S.; Kamatani, N.; Momma, K.; Takao, A.; Nakazawa, M.; Shimizu, N. \& Matsuoka, R. (2003). Role of TBX1 in human del22q11.2 syndrome. Lancet, Vol.362, No.9393, (October 2003), pp. 1366-1373, ISSN 0140-6736

Yan, YT.; Gritsman, K.; Ding, J.; Burdine, RD.; Corrales, JD.; Price, SM.; Talbot, WS.; Schier, AF. \& Shen, MM. (1999). Conserved requirement for EGF-CFC genes in vertebrate 
left-right axis formation. Gene \& Development, Vol.13, No.19, (October 1999), pp. 2527-2537, ISSN 1549-5477

Yu, ZB.; Han, SP. \& Guo, XR. (2008). [A Meta-analysis on the risk factors of perinatal congenital heart disease in Chinese people]. Zhonghua Liuxingbingxue Zazhi, Vol.29, No.11, (November 2008), pp. 1137-1140, ISSN 0254-6450

Zatyka, M.; Priestley, M.; Ladusans, EJ.; Fryer, AE.; Mason, J.; Latif, F. \& Maher, ER. (2005). Analysis of CRELD1 as a candidate 3p25 atrioventicular septal defect locus (AVSD2). Clinical Genetics, Vol.67, No.6, (June 2005), pp. 526-528, ISSN 0009-9163

Zhang, L.; Zhang, XH.; Ren, MH. \& Song, GN. (2010). [Chromosomosome abnormalities and congenital heart diseases: a retrospective on 49 cases]. Journal of Sichuan University. Medical science edition, Vol.41, No.2, (March 2010), pp. 312-315, ISSN 1672-173X

Zhao, F.; Weismann, CG.; Satoda, M.; Pierpont, ME.; Sweeney, E.; Thompson, EM. \& Gelb, BD. (2001). Novel TFAP2B mutations that cause Char syndrome provide a genotype-phenotype correlation. American Journal of Human Genetics, Vol.69, No.4, (October 2001), pp. 695-703, ISSN 0002-9297

Zhu, L.; Harutyunyan, KG.; Peng, JL.; Wang, J.; Schwartz, RJ. \& Belmont, JW. (2007). Identification of a novel role of ZIC3 in regulating cardiac development. Human Molecular Genetics, Vol.16, No.14, (July 2007), pp. 1649-1660, ISSN 0964-6906

Zomer, AC.; Vaartjes, I.; Uiterwaal, CS.; Van der Velde, ET.; Van der Merkhof, LF.; Baur, LH.; Ansink, TJ.; Cozijnsen, L.; Pieper, PG.; Meijboom, FJ.; Grobbee, DE. \& Mulder, BJ. (2010). Circumstances of death in adult congenital heart disease. International Journal of Cardiology, (October 2010), doi:10.1016/j.ijcard.2010.09.015 


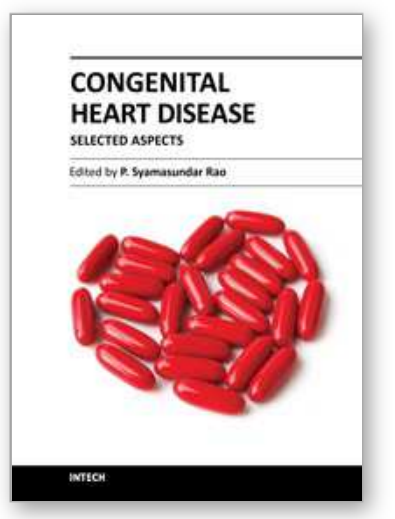

\author{
Congenital Heart Disease - Selected Aspects \\ Edited by Prof. P. Syamasundar Rao
}

ISBN 978-953-307-472-6

Hard cover, 348 pages

Publisher InTech

Published online 18, January, 2012

Published in print edition January, 2012

There are significant advances in the understanding of the molecular mechanisms of cardiac development and the etiology of congenital heart disease (CHD). However, these have not yet evolved to such a degree so as to be useful in preventing $\mathrm{CHD}$ at this time. Developments such as early detection of the neonates with serious heart disease and their rapid transport to tertiary care centers, availability of highly sensitive noninvasive diagnostic tools, advances in neonatal care and anesthesia, progress in transcatheter interventional procedures and extension of complicated surgical procedures to the neonate and infant have advanced to such a degree that almost all congenital cardiac defects can be diagnosed and "corrected". Treatment of the majority of acyanotic and simpler cyanotic heart defects with currently available transcatheter and surgical techniques is feasible, effective and safe. The application of staged total cavo-pulmonary connection (Fontan) has markedly improved the long-term outlook of children who have one functioning ventricle. This book, I hope, will serve as a rich source of information to the physician caring for infants, children and adults with CHD which may help them provide optimal care for their patients.

\title{
How to reference
}

In order to correctly reference this scholarly work, feel free to copy and paste the following:

Jarun Sayasathid, Kanchapan Sukonpan and Naraporn Somboonna (2012). Epidemiology and Etiology of Congenital Heart Diseases, Congenital Heart Disease - Selected Aspects, Prof. P. Syamasundar Rao (Ed.), ISBN: 978-953-307-472-6, InTech, Available from: http://www.intechopen.com/books/congenital-heartdisease-selected-aspects/epidemiology-and-etiology-of-congenital-heart-diseases

\section{INTECH}

open science | open minds

\section{InTech Europe}

University Campus STeP Ri

Slavka Krautzeka 83/A

51000 Rijeka, Croatia

Phone: +385 (51) 770447

Fax: +385 (51) 686166

www.intechopen.com

\section{InTech China}

Unit 405, Office Block, Hotel Equatorial Shanghai

No.65, Yan An Road (West), Shanghai, 200040, China 中国上海市延安西路65号上海国际贵都大饭店办公楼 405 单元

Phone: +86-21-62489820

Fax: +86-21-62489821 
(C) 2012 The Author(s). Licensee IntechOpen. This is an open access article distributed under the terms of the Creative Commons Attribution 3.0 License, which permits unrestricted use, distribution, and reproduction in any medium, provided the original work is properly cited. 